\title{
Effects of observed and experimental climate change on terrestrial ecosystems in northern Canada: results from the Canadian IPY program
}

\author{
Gregory H. R. Henry • Karen A. Harper • \\ Wenjun Chen • Julie R. Deslippe • Robert F. Grant • \\ Peter M. Lafleur • Esther Lévesque • \\ Steven D. Siciliano • Suzanne W. Simard
}

Received: 29 June 2012 / Accepted: 5 September 2012

(C) The Author(s) 2012. This article is published with open access at Springerlink.com

\begin{abstract}
Tundra and taiga ecosystems comprise nearly $40 \%$ of the terrestrial landscapes of Canada. These permafrost ecosystems have supported humans for more than 4500 years, and are currently home to ca. 115,000 people, the majority of whom are First Nations, Inuit and Métis. The responses of these ecosystems to the regional warming over the past $30-50$ years were the focus of four Canadian IPY projects. Northern residents and researchers reported changes in climate and weather patterns and noted shifts in vegetation and other environmental variables. In forest-tundra areas tree growth and reproductive effort correlated with temperature, but seedling establishment was often hindered by other factors resulting in sitespecific responses. Increased shrub cover has occurred in sites across the Arctic at the plot and landscape scale, and this was supported by results from experimental warming. Experimental warming increased vegetation cover and nutrient availability in most tundra soils; however, resistance to warming was also found. Soil microbial diversity in tundra was no different than in other biomes, although there were shifts in mycorrhizal diversity in warming experiments. All sites measured were sinks for carbon during the growing season,
\end{abstract}

Electronic supplementary material The online version of this article (doi:10.1007/s10584-012-0587-1) contains supplementary material, which is available to authorized users.

G. H. R. Henry $(\bowtie)$

Department of Geography, University of British Columbia, Vancouver, BC V6T 1Z2, Canada e-mail: greg.henry@ubc.ca

K. A. Harper

School for Resource and Environmental Studies, Dalhousie University, Halifax, NS B3H 4R2, Canada

W. Chen

Canadian Centre for Remote Sensing, Natural Resources Canada, Ottawa, ON K1A 0Y7, Canada

J. R. Deslippe $\cdot$ S. W. Simard

Department of Forest Science, University of British Columbia, Vancouver, BC V6T 1Z4, Canada

R. F. Grant

Department of Renewable Resources, University of Alberta, Edmonton, AB T6G 2E3, Canada 
with expected seasonal and latitudinal patterns. Modeled responses of a mesic tundra system to climate change showed that the sink status will likely continue for the next 50-100 years, after which these tundra systems will likely become a net source of carbon dioxide to the atmosphere. These IPY studies were the first comprehensive assessment of the state and change in Canadian northern terrestrial ecosystems and showed that the inherent variability in these systems is reflected in their site-specific responses to changes in climate. They also showed the importance of using local traditional knowledge and science, and provided extensive data sets, sites and researchers needed to study and manage the inevitable changes in the Canadian North.

\section{Introduction}

Canada has the greatest variety of northern terrestrial ecosystems of all circumpolar countries. Including the northern boreal forests, peat bogs and mires near the transition from forest to tundra and high Arctic tundra, Canada is home to more than 3 million $\mathrm{km}^{2}$ of these northern landscapes. All of the land area considered here, nearly $40 \%$ of the country, is underlain by continuous or discontinuous permafrost (Tarnocai 1999). These ecosystems have important roles at the local, regional and global scales: as homes to ca. 115,000 people, as habitats for species of plants, animals and microbes, as globally important stores of soil carbon, and as climate regulators through the heat sinks and albedo effects of permafrost, snow and ice. These systems are also undergoing rapid change in response to the recent warming of the global climate: warming in Arctic Canada has been as much as $1{ }^{\circ} \mathrm{C}$ per decade over the past 20-50 years (ACIA 2005; IPCC 2007; Hill and Henry 2011). This background provided the impetus for studies of the northern terrestrial ecosystems in Canada as part of the International Polar Year.

The Canadian IPY program supported six projects that involved research on terrestrial ecosystems. The projects spanned the Canadian North, from northern boreal forests to the high Arctic tundra on northern Ellesmere Island, Nunavut and from Nunatsiavut/Labrador to northern Yukon and Alaska. Nearly all of the projects had sub-projects that involved studies of the effects of predicted climate changes, including assessments of change by elders and other residents of the North. In this paper, we present summaries and a synthesis of some of these major Canadian IPY projects. The results of the projects are presented within a framework of terrestrial ecosystem components and processes in an effort to provide a general synthesis.

The six major projects that examined impacts of climate variability and change on terrestrial ecosystems in northern Canada are presented in Table 1, with some of the

P. M. Lafleur

Department of Geography, Trent University, Peterborough, ON K9J 7B8, Canada

E. Lévesque

Département de chimie-biologie, Université du Québec à Trois-Rivières, Trois-Rivières, QC G9A 5H7, Canada

S. D. Siciliano

Department of Soil Science, University of Saskatchewan, Saskatoon, SK S7N 5A8, Canada

Present Address:

J. R. Deslippe

Landcare Research, Riddet Road, Massey University Campus, Palmerston North 4442, New Zealand 
Table 1 Canadian IPY projects involved in terrestrial ecosystem research

\begin{tabular}{|c|c|c|c|}
\hline Project Name & Project Leader & Objectives/Description & Participants \\
\hline $\begin{array}{l}\text { Climate Impacts on } \\
\text { Canadian Arctic } \\
\text { Tundra Ecosystems: } \\
\text { Multi-scale and } \\
\text { Interdisciplinary } \\
\text { Assessments } \\
\text { (CiCAT) }\end{array}$ & $\begin{array}{l}\text { Greg Henry, University } \\
\text { of British Columbia }\end{array}$ & $\begin{array}{l}\text { Provide assessments of } \\
\text { responses of tundra } \\
\text { ecosystems to climate } \\
\text { variability and change } \\
\text { at local, regional and } \\
\text { national scales using } \\
\text { existing networks, new } \\
\text { sites and methods and } \\
\text { models, and community } \\
\text { based research. }\end{array}$ & $\begin{array}{l}32 \text { co-PIs } \\
257 \text { team } \\
\text { members } \\
110 \text { students } \\
7 \text { postdocs } \\
26 \text { northern } \\
\text { students } \\
46 \text { northern } \\
\text { participants } \\
18 \text { international } \\
\text { collaborators }\end{array}$ \\
\hline $\begin{array}{l}\text { Present processes, Past } \\
\text { changes, Spatio-temporal } \\
\text { variability in the Arctic } \\
\text { delimitation zone, Canada } \\
\text { (PPS Arctic Canada) }\end{array}$ & $\begin{array}{l}\text { Karen Harper, } \\
\text { Dalhousie } \\
\text { University }\end{array}$ & $\begin{array}{l}\text { Determining recent change } \\
\text { in tree and shrub } \\
\text { distributions, correlating } \\
\text { change with environmental } \\
\text { data, investigating } \\
\text { mechanisms, spatial } \\
\text { patterns and the role of } \\
\text { disturbance, and } \\
\text { developing models to } \\
\text { predict future changes } \\
\text { as treeline migrates. }\end{array}$ & $\begin{array}{l}22 \text { co-PIs } \\
212 \text { team } \\
\text { members } \\
82 \text { students } \\
3 \text { postdocs } \\
7 \text { northern } \\
\text { students } \\
82 \text { northern } \\
\text { participants } \\
4 \text { international } \\
\text { collaborators }\end{array}$ \\
\hline $\begin{array}{l}\text { Carbon, Microbial and Plant } \\
\text { Community Dynamics in } \\
\text { Low-Arctic Tundra }\end{array}$ & $\begin{array}{l}\text { Suzanne Simard, } \\
\text { University of } \\
\text { British Columbia }\end{array}$ & $\begin{array}{l}\text { To gain a better understanding } \\
\text { of plant interactions with } \\
\text { mycorrhizal fungi and other } \\
\text { soil microbes that regulate } \\
\text { carbon fluxes in tundra } \\
\text { systems of the Low Arctic. }\end{array}$ & $\begin{array}{l}2 \text { co-PIs } \\
19 \text { team } \\
\text { members } \\
1 \text { postdoc } \\
9 \text { students } \\
4 \text { northern } \\
\text { students } \\
8 \text { international } \\
\text { collaborators }\end{array}$ \\
\hline $\begin{array}{l}\text { Changing Forests and } \\
\text { Peatlands along the } \\
\text { Mackenzie Valley, } \\
\text { Northwest Territories }\end{array}$ & $\begin{array}{l}\text { Jagtar Bhatti, Natural } \\
\text { Resources Canada }\end{array}$ & $\begin{array}{l}\text { To characterize the boreal } \\
\text { forest and peatland } \\
\text { ecosystems along } \\
\text { the Mackenzie Valley, } \\
\text { and their potential for } \\
\text { change. }\end{array}$ & $\mathrm{n} / \mathrm{a}$ \\
\hline $\begin{array}{l}\text { Yeendoo Nanh Nakhweenjit } \\
\text { K'atr'ahanahtyaa: } \\
\text { Environmental } \\
\text { Change and Traditional } \\
\text { Use in the Old Crow } \\
\text { Flats, Yukon (YNNK) }\end{array}$ & $\begin{array}{l}\text { Vuntut Gwitch'in First } \\
\text { Nation, Old Crow }\end{array}$ & $\begin{array}{l}\text { To gain a better understanding } \\
\text { of the environmental changes } \\
\text { in the Old Crow Flats and } \\
\text { their impacts on the } \\
\text { Gwitchi'in people to help } \\
\text { determine adaptation } \\
\text { strategies. }\end{array}$ & $\mathrm{n} / \mathrm{a}$ \\
\hline $\begin{array}{l}\text { Measuring the Impact of } \\
\text { Climate Change on } \\
\text { Landscape and Water } \\
\text { Systems in the High } \\
\text { Arctic }\end{array}$ & $\begin{array}{l}\text { Scott Lamoureux, } \\
\text { Queen's University }\end{array}$ & $\begin{array}{l}\text { The focus was mainly on } \\
\text { hydrology and effects of } \\
\text { landscape change, with } \\
\text { components on ecosystem } \\
\text { research linked to CiCAT. }\end{array}$ & $\mathrm{n} / \mathrm{a}$ \\
\hline
\end{tabular}


information and statistics for each project. Research locations, including communities involved in the IPY projects are shown in Fig. 1. Further descriptions are found in Supplementary Material.

The objective of this paper is to provide an assessment of the state of northern terrestrial systems in Canada and their current and potential responses to the changing climate through a summary and a general synthesis of the results of the major Canadian IPY projects on terrestrial ecosystems. We begin with a section on the use and collaborative links of traditional/local ecological knowledge on terrestrial systems with scientific studies. The following section examines the vegetation in northern systems at regional, landscape and plot scales, and how it has or has not changed over the recent decades. The vegetation section is followed by a section on the research conducted on soil components and processes in northern systems, and how these processes link to and potentially control changes in the

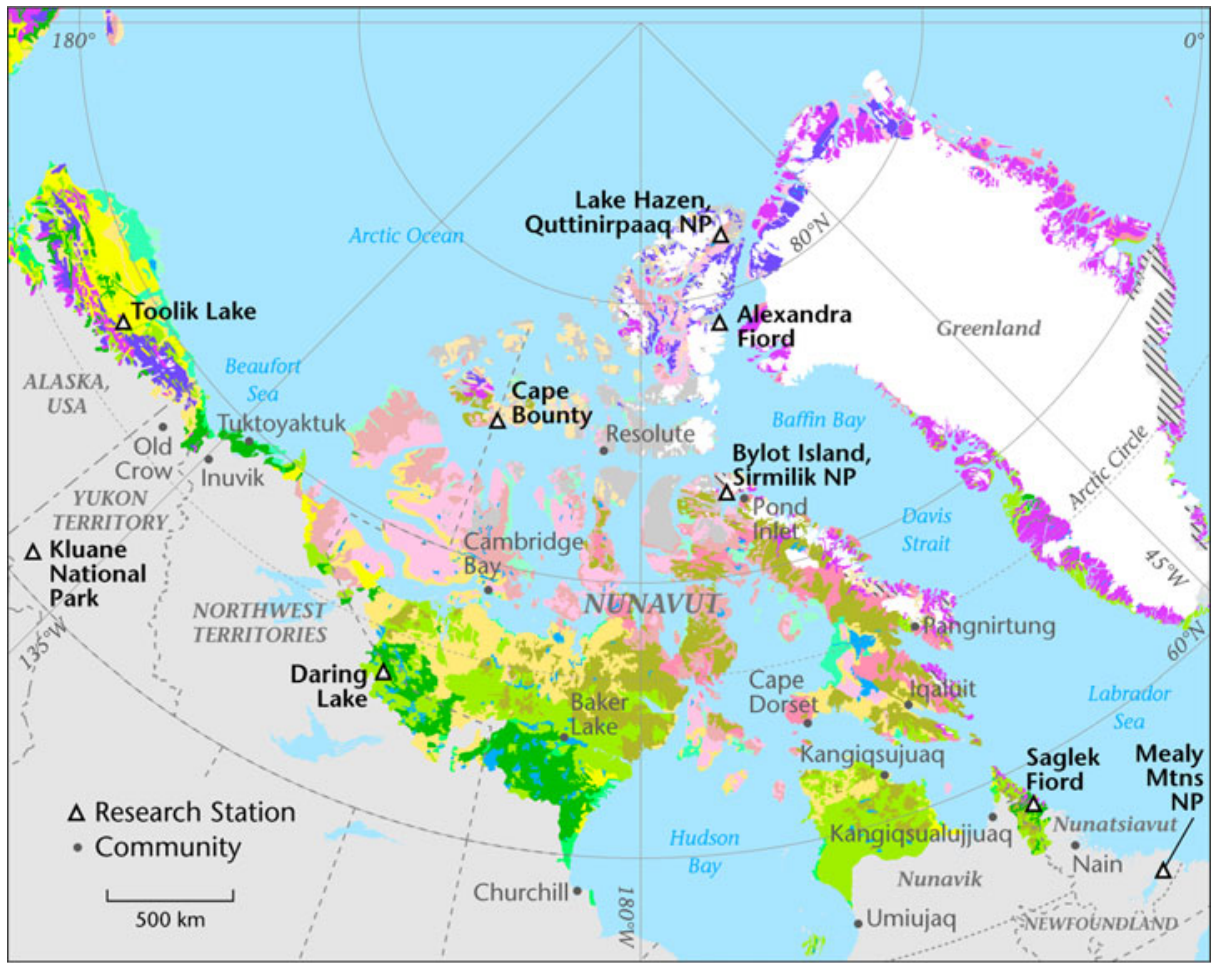

\begin{tabular}{|l|l|}
\hline Circumpolar Arctic Region Vegetation & Erect dwarf-shrub tundra \\
\hline Cryptogam, herb barren & Low-shrub tundra \\
\hline Cryptogam barren complex (bedrock) & Sedge/grass, moss wetland \\
\hline Noncarbonate mountain complex & Sedge, moss, dwarf-shrub wetland \\
\hline Carbonate mountain complex & Sedge, moss, low-shrub wetland \\
\hline Prostrate dwarf-shrub, herb tundra & Nunatak complex \\
\hline Prostrate/Hemiprostrate dwarf-shrub tundra & Glaciers \\
\hline Rush/grass, forb, cryptogam tundra & Water \\
\hline Graminoid, prostrate dwarf-shrub, forb tundra & Lagoon \\
\hline Nontussock sedge, dwarf-shrub, moss tundra & Non-Arctic Areas \\
\hline Tussock sedge, dwarf-shrub, moss tundra & \\
\hline
\end{tabular}

Fig. 1 Locations of sites involved in Canadian IPY projects on terrestrial ecosystems. The general vegetation types of the Circum-Arctic Vegetation Map are shown. A detailed legend for the vegetation types is available at www.arcticatlas.org/maps/themes/cp/cpvg. The southern boundary of the CAVM is the forest-tundra region 
vegetation. The last of the results sections is on the studies of carbon fluxes in tundra ecosystems and the modeling research conducted to understand potential long-term changes in carbon dynamics in these ecosystems in a changing climate. The final section is a summary and synthesis of the major findings from the IPY research on northern terrestrial systems in Canada.

\section{Community-based research}

Humans have inhabited the landscapes in northern Canada for thousands of years. Northern Aboriginal peoples adapted to the challenging environments using seasonal patterns of resources and developed unique and vibrant cultures that endure today. Even the most northern parts of the High Arctic supported humans, with the first groups reaching northern Ellesmere Island approximately 4500 years ago (Park 2010; McGhee 2001). Today there are many groups of northern Aboriginal peoples, and most have settled land claims with the Canadian government and established their own forms of regional and local governments. The largest of these is Nunavut, home to about 30,000 people, predominantly Inuit, in 26 communities spread across 1.7 million $\mathrm{km}^{2}$. The collective knowledge of the people in these northern communities was a major focus of the Canadian IPY program, and provided the impetus for combining standard scientific approaches with more traditional and community-based studies to better understand the impacts of environmental change.

The integration of traditional ecological knowledge (known as Inuit Qaujimajatuqangit - IQ, in Inuit territories) into the IPY projects was partly accomplished through semistructured interviews in communities. In the CiCAT project collaborative studies were conducted in nine communities across three of the Inuit territories of Canada: Nunatsiavut, Nunavik and Nunavut. In each community semistructured interviews were conducted with elders and other community members to determine how the local environments have changed over their lifetimes and to validate measurements of change. The interviews were conducted by the same person in all communities, which aided comparative analyses of responses among the communities. Similar consultative/collaborative research was conducted in the Nunavut communities of Baker Lake, Cape Dorset, Kimmirut and Sanikiluaq as part of the PPS Arctic Canada project. Interviews were conducted with adults in each community between 2007 and 2010.

Community participation was a hallmark of the YNNK project in Old Crow, Yukon. The observations by community members of changes over the past few decades formed the basis for the IPY project (Wolfe et al. 2011). Here we highlight some of the results of this research as it applies to terrestrial ecosystems.

\subsection{Observations of environmental change}

Interviews held in communities across Nunavut, Nunavik and Nunatsiavut showed that people in all communities have noticed changes in the environment over the past $10+$ years, most of which are consistent with a warming climate (Downing and Cuerrier 2011; Fig. 2). The regional nature of the changes was seen in the different answers and emphasis placed on changes in different communities in Nunavik (Supplementary Material Fig. 1). The residents in the two most northern communities (Kangirsujuaq and Kangirsualujjuaq) had similar responses and experiences with environmental 
changes, whereas there was much greater variability in the perceptions of environmental change in Umiujaq, which is found within the forest-tundra transition zone. Similar observations of change were documented by participants in the YNNK project at Old Crow, Yukon, where people have observed significant lowering of water levels and an strong increase in the growth and cover of shrubs, especially species of Salix (Wolfe et al. 2011). (See Supplementary Materials for further observations).

\subsection{Community-based observations of changes in vegetation and berry production}

As part of the community-based research across the Arctic, community members were asked to assess changes in vegetation and the production of edible berries in their area. Specifically, they were asked about their observations on changes in the cover of shrubs and trees, and whether there had been changes in the production and quality of berries at traditional picking areas. In some cases, the assessments of vegetation change were coupled with analysis of historical photographs in the area, including re-photographing the same sites (Tremblay et al. 2012). In most of the communities, permanent study plots were established in areas recommended by elders or that were identified to have undergone changes in berry production or shrub cover over the past few years. In all cases, the berry plots were established with the help of local students in high school science classes as either part of their curriculum or as part of summer science and traditional knowledge camps (Supplementary Materials Fig. 2).

Berries were collected from the permanent plots in communities in 2008-2011. Berry production varied greatly between years and sites across Arctic Canada, with some indication that production appears to be higher in northern, cooler sites for blueberries (Vaccinium uliginosum) (Fig. 3). However, we expect relatively large interannual variability at each site and spatial patterns among sites would become clearer after more seasons of data.

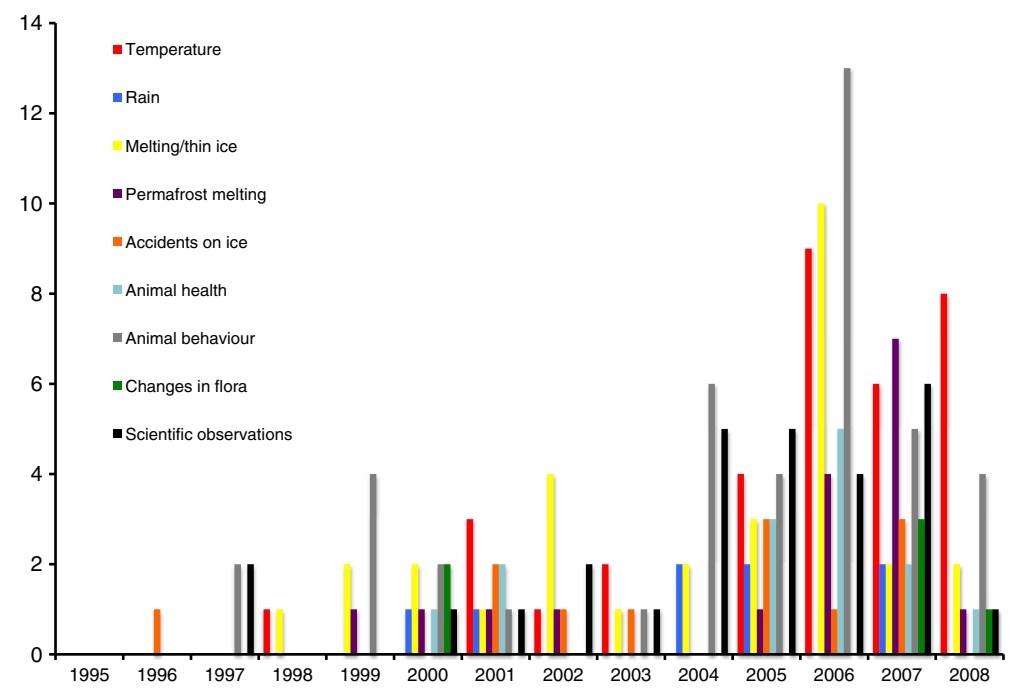

Fig. 2 Frequency of observations linked to climate change from 1995 to 2008 based on Inuit knowledge as reported from the Nunatsiaq News. Based on data from Downing and Cuerrier (2011) 


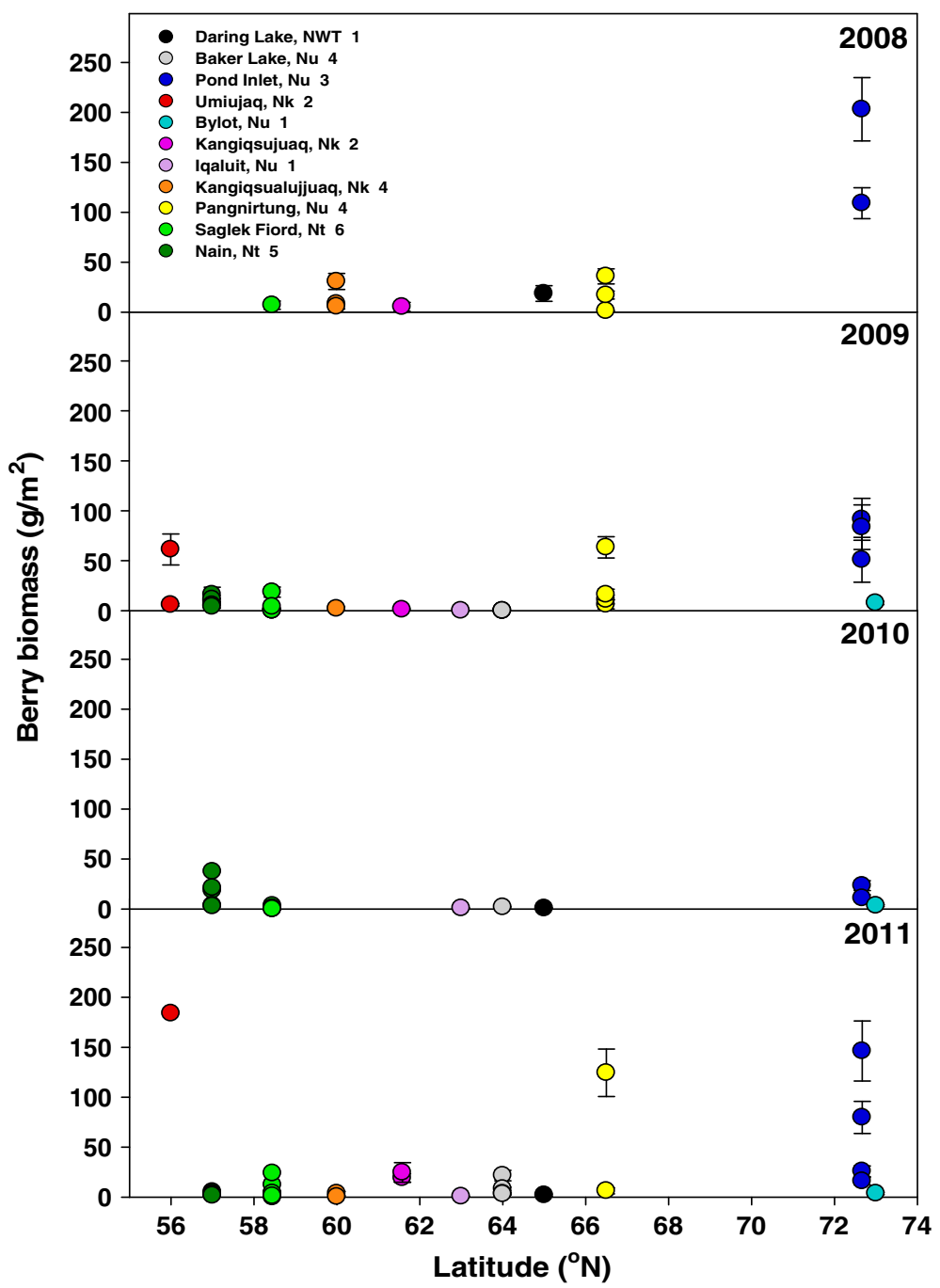

Fig. 3 Vaccinium uliginosum (blueberry) productivity from 2008 to 2011, in relation to site latitude at eleven Canadian Arctic sites. Total number of plots sampled: 10 in 2008; 26 in 2009, 17 in 2010 and 29 in 2011. $\mathrm{NWT}=$ Northwest Territories; $\mathrm{Nu}=$ Nunavut; $\mathrm{Nk}=$ Nunavik and $\mathrm{Nt}=$ Nunatsiavut. The maximum number of plots for each site is shown after the site label. From Henry et al. (2012)

\subsection{Community-based monitoring and education}

The use of berries as a link between traditional ecological knowledge and scientific studies for students in high schools of the north was clearly strong. We found that students were enthralled with the stories of their elders about changes that had taken place over their lifetime and enjoyed the opportunity to work on a science project that involved plants that were connected to the community. An important legacy of these IPY projects will be the incorporation of the measurements of berry production and vegetation change into the science curriculum of Arctic high schools in Canada. For 
example, the Kativik School Board in Nunavik will implement an environmental monitoring module in their secondary school science curriculum in autumn 2012, and berry monitoring will be part of the module.

Cross-cultural workshops held in the Yukon and Nunatsiavut brought together youth, Elders and researchers to learn about plant identification and traditional uses of plants; hands-on activities combined traditional knowledge and science (Cuerrier et al. 2012) (Supplementary Materials Fig. 2). Trant et al. (2012) consulted with the Labrador Innu in the Innu Environmental Guardians Training Program to develop long-term monitoring plots and monitoring protocols to detect change in the boreal forest in Labrador.

See Supplemental Material for further information.

\section{Vegetation}

The Canadian North has a large variety of vegetation types as a result of landscape history, physical geography, climate, soil development and the differential establishment of plant species. Recovery from the last glaciation is still underway (Svoboda and Henry 1987; Johnstone and Chapin 2003), and is accelerated by the warming climate of the North (ACIA 2005). Canada has a vast expanse of forest-tundra ecotone, the broad transition from boreal forest to tundra, stretching across the northern reaches of the continent. The position of this zone reflects the climatic influences on tree growth, and is found under the average position of the boundary between Arctic and temperate air masses in the summer (Timoney et al. 1992) (Fig. 1). It is in this transition zone that important changes in vegetation are expected as the climate warms over the coming decades (Payette et al. 2001; Epstein et al. 2004). The four major vegetation zones of the Circum-Arctic Vegetation Map (CAVM) are found along latitudinal gradients from the forest-tundra transition (Zone E, Fig. 1) to polar desert areas (Zone A) on the outer edges of the Arctic Islands (Gould et al. 2003; Walker et al. 2005). Changes in tundra vegetation over the past few decades have been found in regions throughout the Arctic (ACIA 2005), and have been reported from sites in the Canadian High Arctic (e.g. Hudson and Henry 2010; Hill and Henry 2011). The changes in vegetation will impact wildlife habitat and have feedbacks to processes in these ecosystems and to the earth-atmosphere system. For example, the increasing cover and height of shrubs in the Low Arctic and increased density of shrubs and trees in the forest-tundra will result in a lowered surface albedo, increasing the amount of solar radiation absorbed by these systems and will contribute to additional regional warming (Chapin et al. 2005; Tape et al. 2006; MyersSmith et al. 2012).

Our studies during the IPY spanned the Canadian North, and provided the first coordinated assessment of the current state of terrestrial systems and their potential for change. Regional assessments of vegetation change were conducted using remote sensing and satellite image analyses, as well as studies at the plot and landscape scale. Outlines of objectives and methods can be found in Supplementary Materials. In this section, we review the results of research on vegetation from PPS Arctic Canada, focussed on the forest-tundra ecotone, and CiCAT, which was focused on tundra ecosystems.

\subsection{Evidence for vegetation change: regional scale}

Temporal changes in reflectance from northern areas as detected by satellites have been attributed to changes in vegetation. Most studies report an increase in greenness as measured 
by indices such as the Normalized Difference Vegetation Index (NDVI). Bhatt et al. (2010) show the changes in NDVI in tundra regions over the past 20 years are linked to the decline in sea ice over the same period, which is ultimately linked to warmer temperatures. Olthof et al. (2008) found similar increases in NDVI in two areas of northern Canada between 1986 and 2006 and noted that the changes correlated with the general warming that has occurred in the specific regions and across the Arctic. Furthermore, Wang and Overland (2004) found there has been a loss of the area covered by the Tundra Climate classification over the past 30 years.

Change detection studies were conducted using remote sensing in most IPY projects. Chen et al. (unpublished) found increases in NDVI over the entire range of the Porcupine caribou herd over the twenty-year period 1986 to 2006 (Supplemental Material Fig. 3). The increase in NDVI generally indicates an increase in plant biomass. Interestingly, the Porcupine caribou herd increased from ca. 120,000 to nearly 170,000 animals between 2001 and 2010 (http://carmanetwork.com/pages/viewpage.action?pageId=1114130).

In a similar study of the range of the Bathurst caribou herd, Chen et al. (2012a) noted that there had been a loss of forest cover in the winter range which corresponded to increased fire frequency over the past 50 years. The increased fire frequency correlated well with increasing summer temperatures. The loss of forested area has likely resulted in the loss of lichen biomass, a crucial component of winter forage for caribou. In addition, there was an increase in the ice content of snow largely due to melt-refreeze events through the winter. Greater melt-refreeze, and rain on snow events can make it difficult for caribou to access lichens and other forage through the snow. Furthermore, Chen et al. (2012b) found a decrease in lichen biomass on the calving ground and a general decrease in nitrogen concentration of vascular forage on the summer range of the Bathurst herd. During this same time period the Bathurst herd declined dramatically, from over 500,000 in the late 1990 s to less than 35,000 in the last census (2009; http://carmanetwork.com/pages/viewpage.action?pageId=1114374 ). While there is a correlation between the losses of lichen with increased fire on the range, there is still considerable debate on the constellation of factors that are involved in the decline of the herd. The Bathurst herd has undergone large cycles in population in the past century (Zalatan et al. 2006).

Fraser et al. (2012) examined changes in vegetation in four Arctic National Parks in Canada using Landsat TM and ETM data, and found that there were significant increases in greenness (NDVI) and vascular vegetation that correlated strongly with increasing temperatures over the past 40 years. These results support those of Bhatt et al. (2010) who found increased greenness across the circum-Arctic region.

In the Kluane region of the southwest Yukon, a study of trends of snow melt date, snow free season and NDVI found there was no ubiquitous 'greening' of this region, nor have trends in snow cover been directionally widespread (Danby et al. 2010). However, there was evidence of treeline change from analysis of aerial photographs (Danby and Hik 2007), especially increasing tree size and density in the forest-tundra. The most apparent trend from the satellite image analysis was the substantial interannual variability in both snow and vegetation related indices. Variability in NDVI is partly related to interannual variability in timing of snow melt, illustrating the importance of considering snow-related variables in future ecological monitoring and in models of ecosystem change.

\subsection{Forest-tundra ecotone}

The transition from boreal forest to tundra in Canada varies in distance, extent and species composition across the country. The width of the zone is generally smaller in the northwestern areas of the Yukon and NWT (10 to $50 \mathrm{~km}$ from continuous forest to treeline), where trees are found up to $69^{\circ} \mathrm{N}$, and grows in extent in the central and eastern areas (30 to 
$>100 \mathrm{~km}$ ) (Timoney et al. 1992; Payette 1983). In some areas in the southern zones such as the southern coast of Hudson Bay, the forest-tundra ecotone can be very narrow (e.g. $<10 \mathrm{~km}$ ) because of the strong temperature gradient imposed by the cold water of the Bay. The extent of the zone is determined by many factors, including the history of species migration after the most recent continental glaciation (Ritchie 1987), climatic fluctuations over the Holocene (MacDonald et al. 1993) and topography. Remnants of the previous northern migration of treeline during the medieval warm period (ca. 800-1200 ybp) are found as isolated clonal populations beyond current treeline, and are commonly known as tree islands (McLeod 2001; Walker et al. 2012). Within the latitudinal forest-tundra ecotone, changes in tree density are commonly observed along altitudinal gradients on mountain slopes and even on small hills or ridges in relatively flat areas (Payette and Gagnon 1979). All sampling for PPS Arctic sites was done along these altitudinal gradients, much of which used common protocols for collecting environmental and vegetation data (Hofgaard and Harper 2011; Hofgaard and Rees 2008).

The significant warming within the forest-tundra ecotone in the past few decades would be expected to result in increased tree growth, greater densities and allow trees to grow further north and upslope. However, our results show that treeline response to climate change varies greatly among sites. Evidence of vegetation change was found at some sites. For example, establishment of vigorous deciduous shrubs and trees (e.g. Populus balsamifera) was found above treeline in the Yukon (Savidge 2010), there was some evidence of tree island expansion at sites near Churchill (Harper and Albertsen 2010; Mamet and Kershaw 2011) and young larch (Larix laricina) trees are establishing above treeline in Québec (Dufour-Tremblay et al. 2010). Shrubline (the transition from shrub to non-shrub tundra) was also found to be advancing in alpine areas of the Yukon due to the expansion of willow patches and the presence of young willows (Myers-Smith et al. 2011).

However, much of the evidence for recent change was in assessments of reproduction and growth at individual sites. Radial growth studies at most sites indicated all tree species in the forest-tundra ecotone across Canada respond to warmer temperatures. Radial growth in larch has increased over the past few decades in Quebec (Dufour-Tremblay et al. 2010) but there was no clear evidence for increased radial growth of white spruce (Picea glauca) in the Mackenzie Delta region (Walker 2011). Growth was positively correlated with temperature for spruce trees on the Tuktoyaktuk Peninsula (Walker 2011) and Churchill (Mamet and Kershaw 2011), and for willow shrubs in the Yukon (Myers-Smith 2011). However, the sensitivity to climate was also strongly affected by the site conditions, especially soil moisture. For example, in the Yukon the most sensitive climate-growth responses for white spruce and lodgepole pine (Pinus contorta) were found on dry sites (Miyamoto et al. 2010). Growth in the Mackenzie Delta region was also responsive to warmth in the current season, but was negatively correlated to warmth in the previous season which may indicate a cumulative moisture limitation (Walker 2011). A divergence in the response of white spruce tree ring chronologies to temperature in the Old Crow Flats, Yukon since the mid-20th century is also attributed to moisture stress (Porter and Pisaric 2011). This is similar to results from studies in Alaska where radial growth of spruce tracked increases in temperature in the first 50 years of the 20th century with the correlations decreasing over the last 50 years (McGuire et al. 2010; Andreu-Hayles et al. 2011). However, drought did not limit radial growth of any of the four species in the Mealy Mountains, Labrador due to high precipitation (Trindale et al. 2011). In Labrador, there is a bioclimatic shifting of the climate-radial growth relationship of white spruce at roughly $56^{\circ} 75^{\prime} \mathrm{N}$ resulting in an unusual configuration of tree line in northern Labrador (Nishimura and Laroque 2011). These patterns of 'divergence' in correlation are hypothesized to be the results of factors other than temperature limiting 
growth of trees near treeline (D'Arrigo et al. 2008; Andreu-Hayles et al. 2011) such as insect defoliations in Labrador (Trindale et al. 2011).

Although not direct evidence of treeline advance, seedlings and saplings indicate potential for future increases in tree density within and beyond the forest-tundra ecotone. Abundant seedlings were found at some treeline sites but were scarce at others despite extensive searching and evidence of increasing temperatures (Walker et al. 2012; Jameson unpublished). Change in seedling density over time was only measured at sites in the Mackenzie Delta region where seedlings that had been measured for growth and reproduction in the early 1990s were revisited during the PPS Arctic Canada project. There was no significant increase in white spruce seedling density, production of cones or viable seed, or germination rate despite the increase in summer and annual temperatures over the past 40 years (Fig. 4) (Walker et al. 2012). However, seed production has increased in some areas of northern Canada (Brown et al. 2010) including in northern Quebec where an increase in viable seed production in lichen woodlands over the past 20 years shows that seedling and sapling density is likely to increase in the forest-tundra ecotone over the coming decades (Gamache and Payette 2005; Dufour Tremblay and Boudreau 2011).

Establishment patterns from age distributions were determined for a number of sites and were related to climate, although there was geographic variability. In the Mackenzie Delta region, establishment was related to cool, moist climatic periods (Walker 2011), while in Churchill establishment occurred in warmer years (Mamet and Kershaw 2011). If the increase in temperature in the Mackenzie Delta region results in drier conditions, establishment may be inhibited. However, with earlier snowmelt and greater snow depth in winter the early growing season may provide the moisture conditions for seed germination and establishment.

Despite increasing temperature and tree growth within the forest-tundra ecotone, the lack of seedling establishment at some sites suggests that other factors are limiting treeline advance, factors which may vary among sites. Various experiments (including transplanting seedlings), repeated measurements and observations show that conditions are often favourable to the growth of seedlings once they have established. For example, planted seeds were able to germinate, develop and persist for four years in all habitats in the Mealy Mountains (Munier et al. 2010). Survival of planted seedlings over 15 years in tundra near tree islands in the Mackenzie Delta region showed the climate and soil conditions are not restricting the establishment of trees at the northern edge of forest-tundra ecotone (Walker et al. 2012). However, seedlings planted in tundra near Churchill exhibited signs of severe stress (Mamet and Kershaw 2011). Therefore, there may be a bottleneck to tree expansion in the forest tundra ecotone due to limited seed production or seedling mortality. A lack of viable seed has been hindering recruitment at sites such as the Mealy Mountains, Labrador, in the Yukon (Brown et al. 2010) and in tree islands in the Mackenzie Delta along with the poor dispersal of seed from southern areas (Walker et al. 2012). Herbivory is likely one of the factors affecting seedling establishment. Although almost all pollen grains of conifers were viable in the Mealy Mountains, $<10 \%$ of seeds were viable due to predispersal seed predation by cone insects (Hermanutz et al., unpublished). At the same site, herbivory accounted for 20 $50 \%$ of the mortality of first year seedlings and the exclusion of herbivores resulted in increased growth and decreased seedling mortality (Munier et al. 2010). See Supplementary Materials for further discussion of factors affecting seedling establishment and growth.

\subsection{Arctic tundra vegetation}

Arctic tundra ecosystems cover ca. $28 \%$ of Canada (Gould et al. 2003; Walker et al. 2005). Generally, plant size and diversity continues to decline with latitude with important local 
variations due to topographic controls on snow distribution and moisture availability (Walker 2000). The southern areas of the Low Arctic are dominated by shrubs and there are many species of deciduous shrubs near the forest-tundra ecotone capable of growing to heights $>1 \mathrm{~m}$, while in the High Arctic there are a few species of prostrate deciduous and evergreen shrubs and the vegetation is dominated by herbaceous species. The local landscape variability controls snow distribution and soil moisture, and hence other soil properties, which results in a large variety of tundra plant communities. Gould et al. (2003) delineated 17 different tundra vegetation units in Arctic Canada that could be mapped at the landscape scale from satellite data which were used in the CAVM (Fig. 1) (Walker et al.
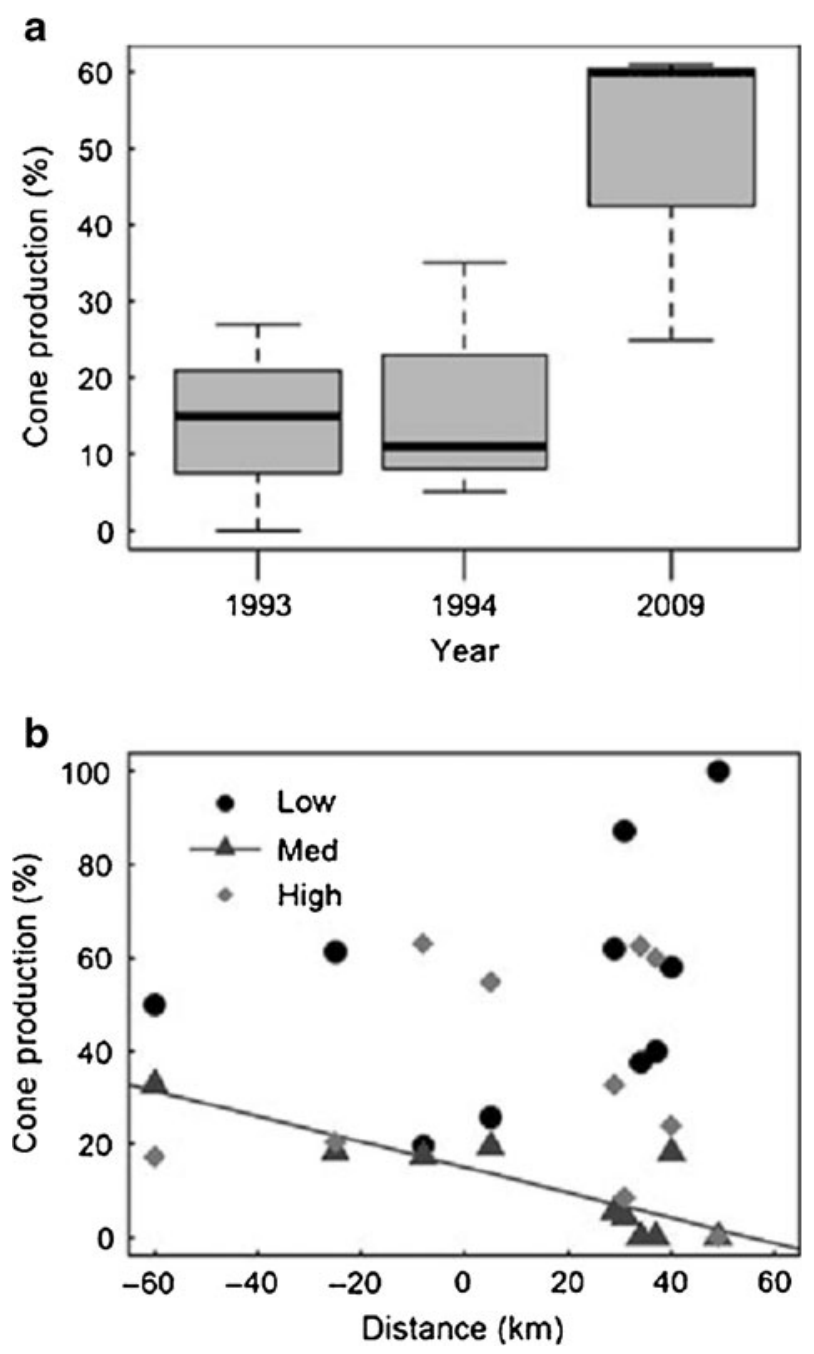

Fig. 4 Proportion of white spruce individuals (a) producing cones in 1993, 1994, and 2009 at tree island sites on the Tuktoyaktuk Peninsula; and (b) producing low, medium, and high levels of cones in 2009 at sites through the forest tundra, correlated with distance from treeline. Treeline defined as in Timoney et al. (1992). Trendline indicates a significant relationship $(\rho s=-0.742, P=0.013)$. Positive and negative values on the $\mathrm{x}-$ axis indicate north and south of the treeline, respectively. From Walker et al. (2012) 
2005). The strong variation in soil moisture and snow cover imposed by microtopography is seen in the complex of plant communities at small spatial scales (e.g. Muc et al. 1989; Walker 2000). Many species of tundra plants have wide ranges of tolerance and are found in a variety of habitats, and plant communities can have rather subtle differences in composition (Muc et al. 1989). Occupying a range of habitats has likely resulted in a number of ecotypes of species, and the responses of each species to environmental change will depend partly on the ecotype (Bennington et al. 2012).

Tundra systems are known to be restricted by nutrient supply (Chapin et al. 1995), largely due to the cold permafrost soils that result in poor decomposition and mineralization. Warming will have direct effects on tundra systems by increasing temperature limited biological activity, but these will likely be mediated through secondary effects, especially effects on soil processes involved in nutrient dynamics.

Species responses to environmental change have been followed in experimental studies throughout the circum-arctic region for $>30$ years in some sites (Chapin et al. 1995; Henry and Molau 1997). Phenology and growth are both stimulated by warming with greater growth response in more southern Arctic sites (Arft et al. 1999); although, there is considerable annual variation, dependent on the date of snow melt (Henry et al., unpublished). Reproductive effort and success in high Arctic plant species were stimulated by long-term (12 y) passive warming, with greater seed weight and germination rates, especially in shrub and graminoid species (Klady et al. 2011). These changes indicate a potential shift in vegetation composition with warming, although longitudinal studies of seedling establishment and survival would be required to verify changes over time. However, the general pattern of increased reproductive effort and success in shrubs and graminoids supports the changes found in long-term assessments of species composition and abundance of tundra systems (Walker et al. 2006; Elmendorf et al. 2012b).

Long-term and repeated measure studies show there have been responses in tundra systems to general warming over the past 20-30 years. Increased shrub cover and height has been found at a number of sites along the southern Low Arctic and in the forest-tundra (Myers-Smith et al. 2012; Ropars and Boudreau 2012). The changes in shrub cover in the Canadian Arctic are part of a clear circum-Arctic signal of shrub responses to climate changes over the past 50 years (Tape et al. 2006; Lantz et al. 2009; Lantz et al. 2010; Elmendorf et al. 2012b; Myers-Smith et al. 2012). The increase in shrub density is predicted to result in important feedbacks to the atmosphere and to ecosystem structure and processes. The darker and denser canopy will lower albedo and increase net radiation and lead to greater regional and global warming (Chapin et al. 2005). The taller shrubs will enhance snow depth and affect winter soil temperatures, which could result in greater rates of soil processes and greater nutrient availability (Sturm et al. 2005). The increased dominance of shrubs will have implications for herbivores, especially species such as caribou who depend on the mixture of lichens, herbaceous and woody plants.

Research on responses of High Arctic tundra systems to climate variability and change has been conducted at Alexandra Fiord, Ellesmere Island, Nunavut, an important site in the ITEX network, since 1980 (Svoboda and Freedman 1994; Henry and Molau 1997). As part of the IPY research, Hudson and Henry (2009) found changes in permanent plots in a heath community over the past 15 years were consistent with the predictions from warming experiments (Walker et al. 2006; Hudson and Henry 2010; Hudson et al. 2011; Elmendorf et al. 2012a). There had been an increase in the cover of evergreen shrubs and bryophytes (Fig. 5), although there were no changes in other growth forms and the number of species remained the same. In a similar study, Hill and Henry (2011) found significant increases in 
biomass of wet sedge tundra over the past 30 years: above ground biomass had increased by $140 \%$ and root biomass was $67 \%$ greater than in the early 1980 s. The increased net primary production was strongly correlated with an increase of $3{ }^{\circ} \mathrm{C}$ in average temperature over the past 40 years (Hill and Henry 2011).

These site-specific results were part of an IPY synthesis of vegetation change throughout the tundra biome over the past 30 years, using long-term data from permanent plots and from re-measurement of sites that had been previously assessed throughout the tundra biome (Elmendorf et al. 2012b). As in the Canadian studies, there was a general increase in height and abundance of major growth forms, especially shrub species, and a decrease in the abundance of lichens and bryophytes (Supplementary Materials Fig. 4). While these changes correlated strongly with the warming across the tundra regions, the greatest changes occurred in sites that were already warm, such as Low Arctic areas near the forest-tundra (Elmendorf et al. 2012b).

The changes in the tundra vegetation over the past 30 years were consistent with the results from warming experiments (Walker et al. 2006; Elmendorf et al. 2012a). The experiments also showed significant changes in plant biodiversity, with increases in abundance of shrubs and graminoids and decreases in mosses and lichens (Supplementary Materials Fig. 5).

\section{Soils and belowground processes}

During the IPY, studies were conducted on the spatial variability of soil properties and processes, especially as related to the production and emission of greenhouse gases $\left(\mathrm{CO}_{2}\right.$, $\mathrm{CH}_{4}$ and $\mathrm{NO}_{2}$ ). In this section, we review the results of studies conducted on soils in a number of Canadian tundra sites in the and at Toolik Lake, Alaska.

The permafrost soils of the northern terrestrial regions of Canada contain ca. $40 \%$ of the soil carbon of the country (Tarnocai 1999). Tarnocai et al. (2009) calculated that permafrost soils in the Northern Hemisphere contain $50 \%$ of the soil carbon of the planet, double that of

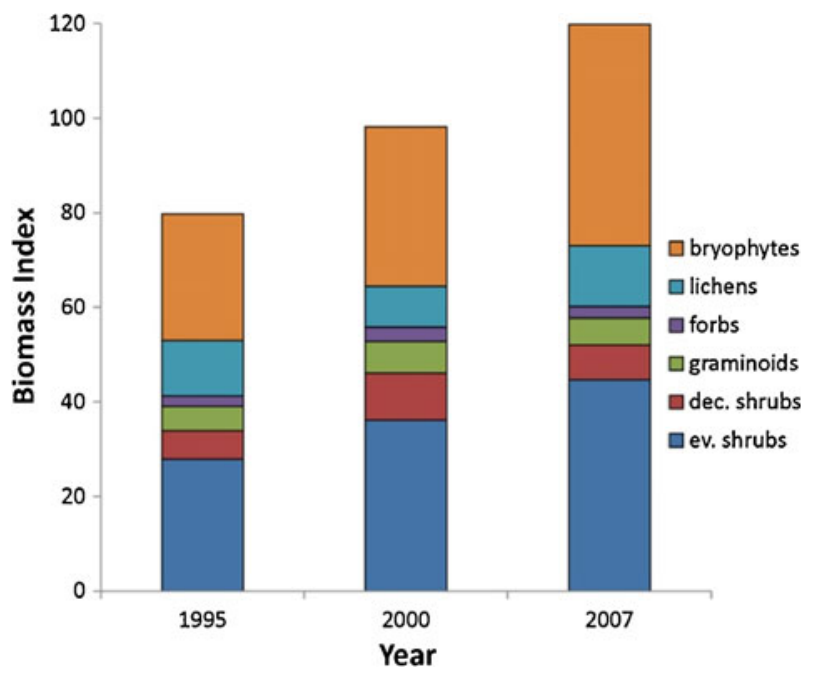

Fig. 5 Changes in biomass of functional groups in permanent plots in tundra heath vegetation at Alexandra Fiord, Ellesmere Island. From Hudson and Henry (2009) 
previous estimates. Much of the carbon is frozen in the permafrost, which is found under nearly $50 \%$ of the soils in Canada. Hence, melting permafrost will lead to greater availability of soil carbon for oxidation by soil microbes, and could become an important extra source of $\mathrm{CO}_{2}$ and $\mathrm{CH}_{4}$ to the atmosphere (Schuur et al. 2008).

\subsection{Nitrogen fixation}

The warmer climate could also result in more productive ecosystems, with nutrient availability increased because of greater decomposition and mineralization (Rolph 2003; Schimel et al. 2004). Nitrogen fixation will also be affected, and studies at high and low Arctic sites showed that nitrogen inputs from $\mathrm{N}$-fixation was nearly twice that through precipitation at a Low Arctic site and was highest in wet sedge communities with abundant bryophytes (Stewart et al. 2011a). Previous studies at a high Arctic site showed that experimental warming had a positive effect on $\mathrm{N}$-fixation and altered the microbial community structure and genotype richness of both nosZ and nifH (Deslippe et al. 2005; Walker et al. 2008). However, the differences in soil processes such as $\mathrm{N}$-fixation and microbial structure and genotype frequency were much greater between plant communities than the effect of experimental warming in any single community. Similarly, Stewart et al (2011b) found that N-fixation in a low Arctic birch hummock community was not strongly related to the abundance of nifH over the season in either hummock or hollow locations, suggesting that nutrient availability, especially $\mathrm{P}$ was a greater limitation to $\mathrm{N}$-fixation than the abundance of $\mathrm{N}$-fixing microorganisms. Microtopographic controls on moisture supply also strongly affect the rate of $\mathrm{N}$-fixation, with rates in hollows $15 \mathrm{x}$ higher than on hummocks (Stewart et al. 2011b). A comprehensive survey of factors affecting N-fixation across Arctic environments showed that water availability as it affected the abundance of bryophytes was an important control on fixation rates in tundra systems (Stewart et al. 2011c). The supply of $\mathrm{N}$ through fixation, while relatively low compared to cycling processes in the soil, may limit the development of vegetation in areas such as polar deserts despite a warming climate.

\subsection{Belowground responses to experimental manipulations}

In an assessment of the effects of factorial combinations of warming and fertilization of a high Arctic shrub heath, Lamb et al. (2011) found essentially no effect on soil microbial diversity. The treatments increased plant cover and height, but had little effect on the abundance of important nitrogen cycling genes or emissions of $\mathrm{CO}_{2}, \mathrm{CH}_{4}$ or $\mathrm{N}_{2} \mathrm{O}$. The resistance of this soil system to change is curious, but the lack of shift in microbial diversity in response to treatments supports the lack of significant difference in diversity among soils at the global level (Chu et al. 2010) (Supplemental Material Fig. 6).

In contrast to the High Arctic site, Deslippe and Simard (2011) found changes in the structure of soil fungal and bacterial communities in organic and mineral soil horizons in plots warmed by greenhouses for 18 years and in control plots at the Arctic Long-term Ecological Research site at Toolik Lake, Alaska. They found that microbial communities were temporally stable, but strongly structured by warming. Warming led to a reduction in the diversity of bacteria and an increase in the diversity of fungi. Reductions in the diversity of bacteria occurred most strongly in the organic soils, where temperature change was greatest, and were associated with a significant increase in the dominance of the Actinobacteria and a significant reduction in the Proteobacteria. The increase in fungal diversity with warming was driven by the important ectomycorrhizal fungi Russula spp., Cortinarius spp., and members of the Helotiales suggesting that increased growth of the shrub Betula nana was an important mechanism driving this change (Deslippe and Simard 2011). 
4.3 Mycorrhizal associations and the expansion of shrub and tree species

Many tundra plant species form symbiotic associations with mycorrhizal fungi, especially shrub species (Kohn and Stasovski 1990; Deslippe et al. 2011). These associations are known to increase the ability of plants to access water and nutrients, and are expected to respond to climate change (Agerer 2006; Deslippe et al. 2011) and hence, will affect the composition and abundance of plants. This could be especially true for deciduous shrub species and could help to explain the current increase in shrub cover found in many Arctic regions (Deslippe et al. 2011; Myers-Smith et al. 2011; Elmendorf et al. 2012b).

Deslippe et al. (2011) examined the ectomycorrhizal community of the deciduous shrub Betula nana in experimental plots at Toolik Lake. The plots had received factorial combinations of warming and fertilization for $>20$ years and B. nana had responded strongly to the treatments, and had increased in abundance in the control plots (Chapin et al. 1995). Warming caused an increase in the diversity of the ectomycorrhizal community, whereas fertilization decreased the diversity (Fig. 6). Warming also caused
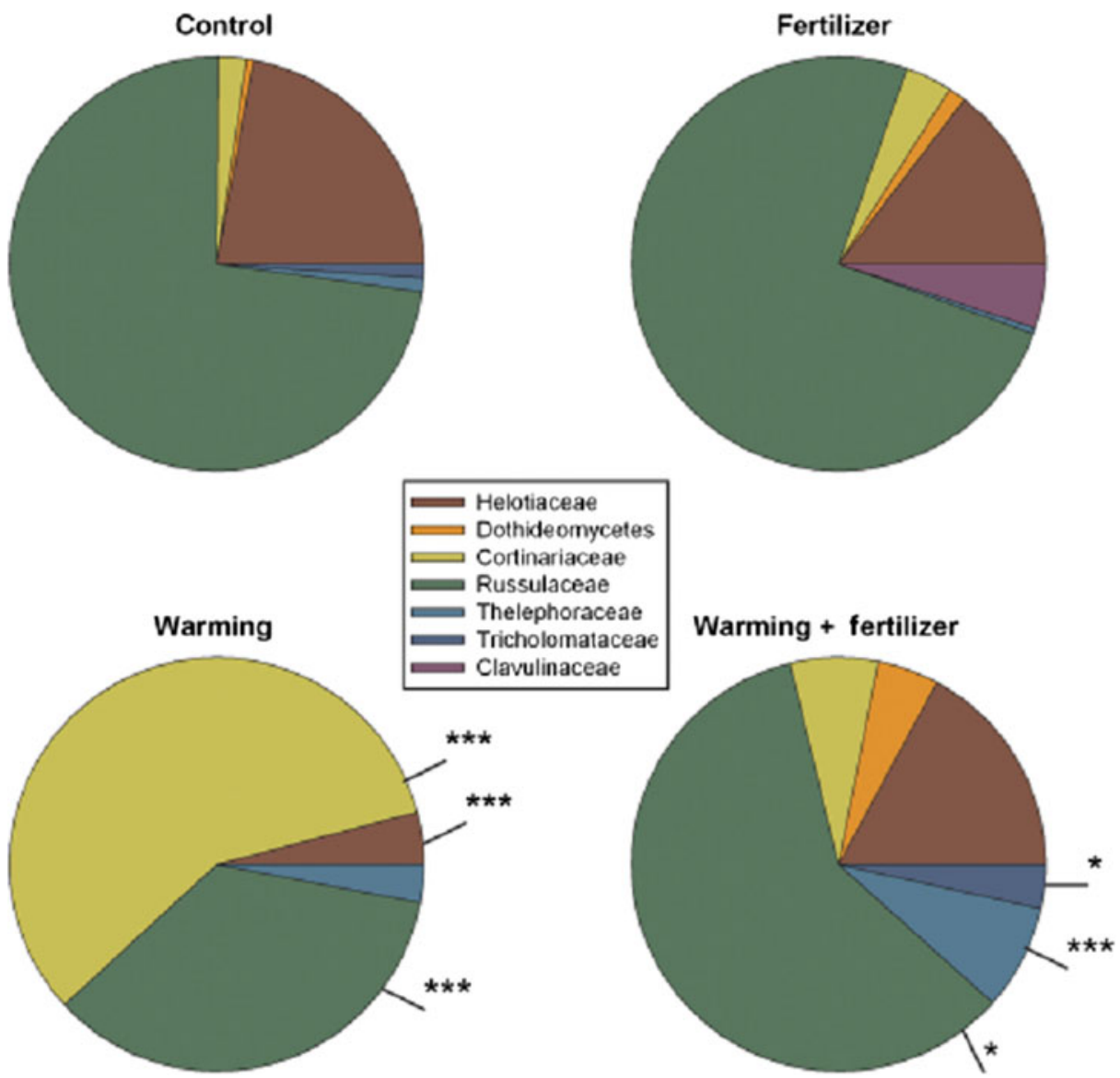

Fig. 6 Proportion of clones affiliated with ectomycorrhizal fungal families in clone libraries constructed from Betula nana root tips from the four treatments at the Arctic LTER site, Toolik Lake, Alaska. Significant treatment effects, relative to the control are denoted by symbols as follows: $* P<0.05, * * * P<0.001$. From Deslippe et al. (2011) 
a shift to species with greater biomass, and potential to access a greater soil volume. In a related study, Deslippe and Simard (2011) found that there was considerable carbon transport between $B$. nana plants through their ectomycorrhizal networks. None of the other species investigated showed this ability. Hence, expansion of deciduous shrubs such as $B$. nana in the warming climate will likely be enhanced by the shift to larger mycorrhizal networks and the ability to transport carbon from older plants to newly established individuals (Deslippe and Simard 2011; Deslippe et al. 2011).

The ability of conifer species to form ectomycorrhizal associations is expected to influence their ability to grow in areas above or beyond the current tree limit. In an examination of mycorrhizal associations in the forest tundra of the Mealy Mountains, Labrador, conifer seedling growth was correlated to the amount of ectomycorrhizal colonization and availability of soil nutrients (Reithmeier 2011). Seedlings were found to have greater ectomycorrhizal colonization and growth when grown in soils that had supported species of Salix than in Arctostaphylos or Betula soils, although the richness and diversity of ectomycorrhizae were not significantly different (Reithmeier 2011). Alternate host plants above the current treeline, such as Salix spp., could potentially facilitate ectomycorrhizal colonization and establishment of trees expanding into higher elevations or northern habitats through their existing networks of colonized roots and mycelia (Reithmeier 2011).

\section{Carbon fluxes in tundra ecosystems: measurements and modelling}

The exchange of radiatively active gases (i.e., greenhouse gases, GHGs) between ecosystems and the atmosphere is fundamentally important to the state of the climate system. Two GHGs of critical concern are carbon dioxide $\left(\mathrm{CO}_{2}\right)$ and methane $\left(\mathrm{CH}_{4}\right)$, both of which are regulated by complex biophysical processes. Understanding the magnitude and direction of the exchange of these gases and how they might vary in response to climatic change is a major scientific challenge and is increasingly important as these systems respond to global warming. In Arctic tundra regions these challenges are complicated because of several factors. The large expanse of circumpolar tundra and great variety of vegetation communities suggest that the response of GHGs to climate change will be complex. Large changes in climate (temperature and precipitation) are expected throughout the Arctic, but magnitude of these changes will vary regionally. The large store of carbon in permafrost soils of northern ecosystems shows that they have been sinks for atmospheric $\mathrm{CO}_{2}$ for long periods of time, and likely throughout the Holocene for many areas (Tarnocai et al. 2009). It is unclear whether these systems will continue to be sinks or will become sources as the soils warm and microbial activity increases the oxidation of the buried carbon. Finally, the response of permafrost will have both positive and negative impacts on GHG exchanges (Schuur et al. 2008).

This heterogeneity adds further complexity to characterizing GHG fluxes in tundra environments and is responsible for widely varying fluxes in a given area (Oechel et al. 2000; Heikkinen et al. 2004). Moisture is an important control on the $\mathrm{CO}_{2}$ and $\mathrm{CH}_{4}$ exchanges both temporally and spatially. Temporally, drying tends to decrease both $\mathrm{CH}_{4}$ emissions and net ecosystem production (NEP = the difference between gross ecosystem production (GEP) and ecosystem respiration (ER)) at a given site (Griffis et al. 2000; Olivas et al. 2010). Spatially, fluxes vary along moisture gradients, but in part this variation can be attributed to vegetation changes along the moisture gradient (Welker et al. 2004; Oberbauer et al. 2007). Increases in temperature generally enhance $\mathrm{CH}_{4}$ emissions. Temperature effects 
on NEP are more complex because increased temperature can increase both GEP and ER and the overall effect on NEP may therefore vary between sites as physiological responses vary among species; hence, different ecosystems will respond differently. This underscores the varying results from experimental manipulations at tundra sites.

Experimental warming of tundra increases gross primary productivity (GPP) and ecosystem respiration (ER) in most studies (Oberbauer et al. 2007; Edwards 2012). However, increases in ER were generally greater than those of GPP at drier sites, where below-ground ER was stimulated by soil warming. In wetter sites, below-ground ER was limited by poor aeration. Thus, experimental warming reduced NEP of moist tussock tundra but increased that of wet sedge tundra in Alaska (Oberbauer et al. 2007). However, in the Canadian High Arctic warming increased NEP of dry and mesic sites, while reducing that of a wet site (Welker et al. 2004). Warming effects on NEP are therefore likely to depend on initial site conditions and the interactions among site conditions, landscape hydrology and climate (Shaver et al. 2000).

Temperature and precipitation have strong influences on the exchanges of $\mathrm{CO}_{2}$ and $\mathrm{CH}_{4}$ at all scales, and they are focus of climate change impacts on carbon cycle feedbacks in the Arctic. The predicted increases in both temperature and precipitation will impact the magnitudes and directions of the fluxes (ACIA 2005). Predicting these impacts is a crucial task for ecosystem models. These models must be sufficiently advanced to simulate the soil and plant processes responsible for GHG exchanges and at the same time be able to operate over long time scales and large spatial areas. Scenarios of future climates are derived from global climate model projections and the ecosystem models run with these conditions to predict future fluxes of $\mathrm{CO}_{2}$ and $\mathrm{CH}_{4}$. While there may be considerable uncertainty surrounding these predictions, because of uncertainty in the climate predictions and model complexity and assumptions, confidence in the predictions is derived from comparisons of model output based on current climate and vegetation conditions with fluxes measured on the tundra. This process is also important because the coupling of measurements and models helps us to understand where models may need improvement. (See Supplementary Materials for a short history of carbon flux research the Canadian Arctic).

During 2008, as part of the CiCAT IPY project, fluxes of $\mathrm{CO}_{2}$ and $\mathrm{CH}_{4}$ were measured over a wide variety of tundra in the Canadian Arctic (Fig. 1; see Lafleur et al. (2012) for site details). We undertook studies of the carbon flux over eight tundra sites from near treeline to the High Arctic and a range of tundra types from wet sedge meadow to high Arctic polar semi-desert. Both towerbased eddy covariance and chambers methods were used. Although specific projects had their own goals, the overall objectives were to assess the exchange of greenhouse gases (mainly $\mathrm{CO}_{2}$ and $\mathrm{CH}_{4}$, but also other gases) between Arctic terrestrial environments and the atmosphere, and determine the importance of these exchanges for global warming and their sensitivity to climate change. In this section, we summarize the results of the measurements made during the IPY, and include results from modeling of these fluxes using an ecosystem model.

\section{Results and discussion}

Complete records of whole ecosystem flux of $\mathrm{CO}_{2}$ were only available for the month of July, but clearly showed that all sites indicate a diurnal amplitude in NEP and were net sinks for $\mathrm{CO}_{2}$ (positive NEP) during this period (Fig. 7). There was a clear distinction between low- and highArctic tundra sites, with the relatively unproductive high Arctic sites (HZ, CB, PI, IQ) having smaller diurnal amplitudes and significantly lower NEP. The latitudinal gradient is not strictly followed, for example Iqaluit (IQ) is at similar latitude to the Daring Lake (DL) sites, but its 

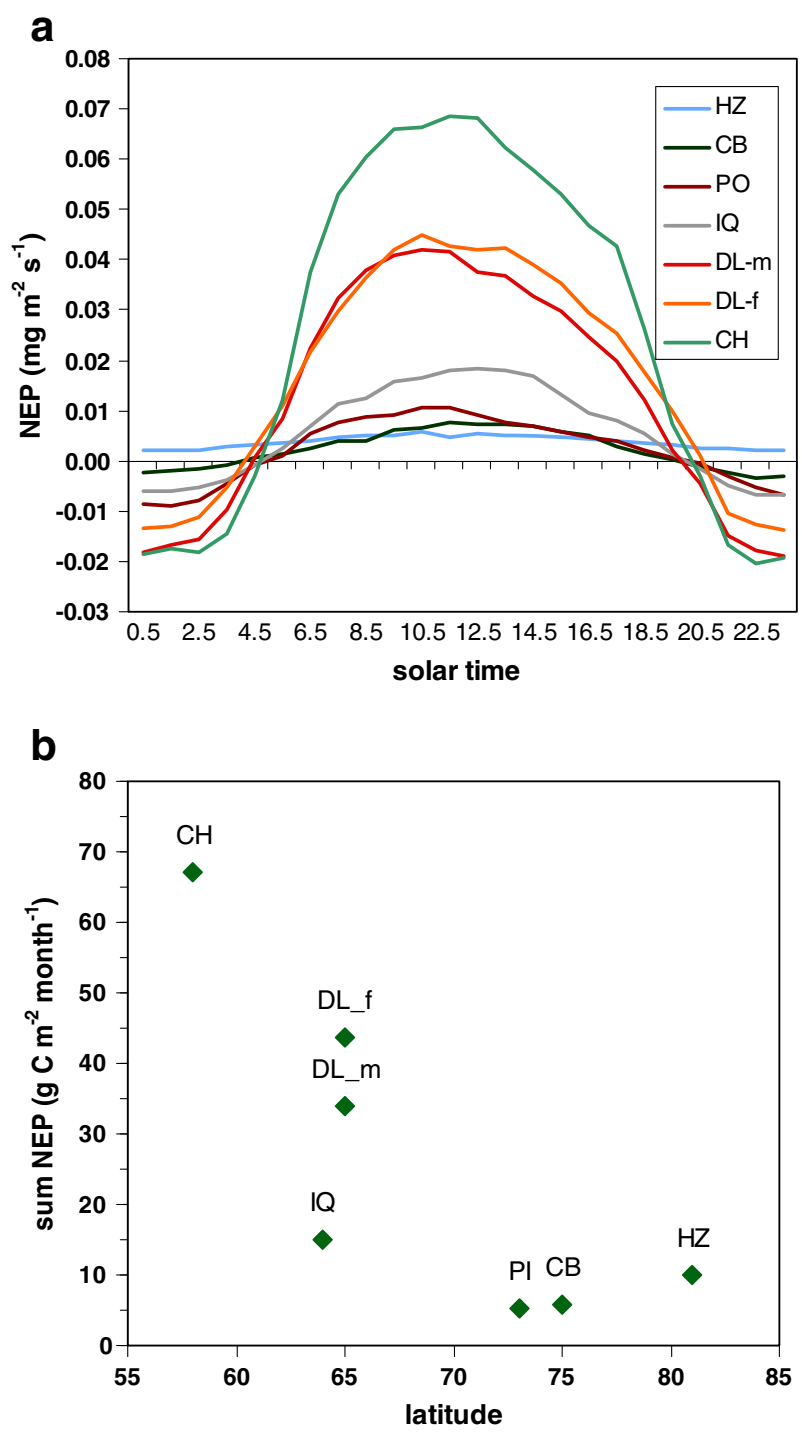

Fig. 7 a Diurnal variation in net ecosystem production (NEP) at seven tundra sites in the Canadian Arctic (Churchill, CH; Daring Lake wet fen, DL_f; Daring Lake mixed upland, DL_m; Iqaluit, IQ; Pond Inlet, PI; Cape Bounty, CB; Lake Hazen, HZ). b Total NEP during July 2008 for sites in panel (a) displayed as a function of latitude in degrees North. See Fig. 1 for locations. From Lafleur et al. (2012)

NEP is more similar to the high-Arctic sites. Iqaluit is located on the coast of Frobisher Bay and its proximity to the Arctic Ocean results in mean July temperature that is $6{ }^{\circ} \mathrm{C}$ below that at DL, consequently the site contains only about half the biomass of DL. In addition, the highest latitude site (Lake Hazen, HZ) did not have the smallest monthly NEP. Twenty four hourday length and fair weather contributed to greater NEP than at either Pond Inlet (PI) or Cape Bounty (CB).

The only sites with multiple-year records were the mixed upland tundra (DL_m) and sedge fen (DL_f) at Daring Lake, NT. Although both sites display considerable interannual variability in growing season NEP, variation is somewhat larger at the wet fen site 
(Supplementary Materials Fig. 7). It has been previously shown that this interannual variation is related to growing season maximum GEP (Humphreys and Lafleur 2011).

Periodic observations of carbon fluxes were conducted with chamber systems in a number of different experiments during IPY. These experiments are of great value because they can isolate individual species or communities and highlight the spatial variation in $\mathrm{CO}_{2}$ and other greenhouse gas fluxes from tundra. See Supplementary Materials for further information on measurements of $\mathrm{CO}_{2}$ and $\mathrm{CH}_{4}$ fluxes from chamber systems.

To date, the only detailed modelling study of tundra biophysical processes and GHG exchange on Canadian Arctic tundra was undertaken by Grant et al. (2011). The ecosys model (Grant 2001) was used to simulate current and future $\mathrm{CO}_{2}$ exchanges at the Daring Lake mixed tundra site. Simulations of current NEP had high correspondence with the fluxes measured from the eddy covariance system and was used to test three hypotheses: (i) annual net primary production (NPP) and heterotrophic respiration (ER) both increase in warmer years with longer growing seasons and are lower in cooler years with shorter growing seasons; (ii) interannual variability in NPP is larger than that in ER and causes NEP to rise in warmer years and to decline in cooler years; (iii) mid-summer warming events (e.g., $\mathrm{T}_{\mathrm{a}}>20^{\circ}$ C) increase ER more than NPP and thereby briefly lower NEP. Changes in NPP and ER arising from these hypotheses supported two further hypothesis based on model projections of NEP under a climate change scenario. First, NPP, ER and their interannual variability increased with warming during the first 100 years of climate change, causing increases in

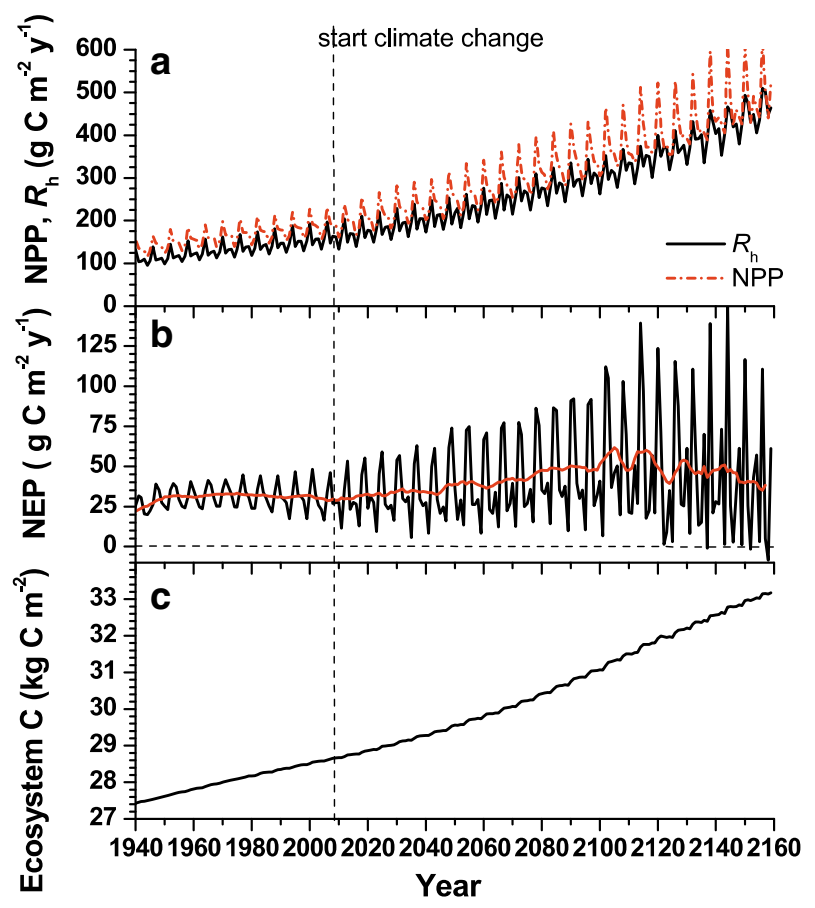

Fig. 8 a Heterotrophic respiration $(\mathrm{Rh}=\mathrm{ER})$, net primary productivity $(\mathrm{NPP}),(\mathbf{b})$ net ecosystem productivity (NEP) and its running average, and (c) ecosystem $\mathrm{C}$ modelled during a continuous 150-year model run under repeating sequences of weather data recorded at Daring Lake from 01 Jan. 2004 to 31 Dec. 2007. These weather data were altered hourly during model years 2008 to 2157 according to climate change predicted by the Canadian Regional Circulation Model (CRCM) v4.2 grid cell within which the Daring Lake site is located. From Grant et al. (2011) 
NEP and its interannual variability (Fig. 8). These greater increases in NPP were largely driven by more $\mathrm{N}$ mineralization with greater ER in warming soil. Second, increases in ER gradually exceeded those in NPP after more than 100 years of climate change as mid-season warming events became more frequent and intense, causing NEP to decline.

This modelling study raises important implications for climate change. The $\mathrm{CO}_{2}$ sink strength of this tundra type increases with future warming; however, the process is limited in time. The model showed this tundra type will begin to add to the atmospheric $\mathrm{CO}_{2}$ burden approximately a century from the present. Although these results pertain to only one site, they underscore the need for continued measurements and modelling of other types of Arctic tundra.

\section{Summary and synthesis}

The vast northern terrestrial ecosystems in Canada provide vital services to local communities including habitats for wildlife and catchments for drinking water, and at the regional and global scales act as regulators for biogeochemical cycling and climate. The studies of these systems during the IPY have shown they are changing, and that changes are in response to the changing climate. However, there is considerable variability in the responses, as would be expected given the enormous variation in ecosystems across the Canadian North. Northern residents, especially Inuit and First Nation people, have an intimate knowledge of the changes and have shown how their ecological knowledge (e.g. IQ) provides the necessary context for understanding the changes in the ecosystems which affect them directly. Their observations of changing phenology of species and the timing of events in the physical environment, changes in vegetation composition and abundance and other environmental components have greatly contributed to the understanding of the variability in the responses of these systems. The combination of local knowledge and scientific study in the berry shrub projects and plant workshops in Arctic communities has given high school students the opportunity to learn how the ecological knowledge of their elders can be combined with standard scientific approaches, which will hopefully inspire some of them to pursue a scientific career. This would be a great legacy of the IPY.

In our studies during the IPY, there were three other major interrelated efforts: to assess the changes or potential changes in vegetation and the processes involved in response to climate change; to better understand the effects of environmental change on the soil processes that will affect how these ecosystems respond; and to measure and model the carbon fluxes in tundra ecosystems. In all of the projects, an overarching goal was to provide both the context for and predictions of the changes in these systems. We found important shifts in vegetation at the regional scale indicating an increase in plant growth (NDVI) over time and a decrease in lichen cover in the forest tundra in the central Arctic, likely as a result of increased fire frequency. These changes could impact the caribou populations that depend on lichen cover for winter forage. Both of these results fit expected responses in a warming climate, and show the variation in response to climate change. The changes in vegetation will depend on the responses of individual species to warming temperatures, altered precipitation regimes and changes in disturbance, such as fire and insect damage, but also industrial activities. In the forest-tundra regions there have been increases in tree growth and reproductive variables over the past few decades, but no clear widespread increase in tree cover or recruitment. Tree islands are unlikely to become important nodes of tree expansion due to lack of seedling establishment and relatively poor seed production (Walker et al. 2012). Areas with adequate moisture for both seed production and seedling establishment will likely see increases in tree density in the coming decades (Brown et al. 2010). This process will be delayed in areas with dry soils or where precipitation decreases or becomes more variable, and there may be areas of degradation 
in forest cover with increased fire frequency (Brown and Johnstone 2012; Chen et al. 2012a) and the potential for greater disturbance by insect pests as their ranges expand northward.

Changes in shrub cover in forest-tundra and tundra regions is thought to be one of the most important effects of climate change in these northern systems because of the potentially strong feedbacks to climate through changes in albedo (Chapin et al. 2005) and influences on other ecosystem processes (Myers-Smith et al. 2011). Increases in NDVI in these regions is often related to the greater growth and cover of shrubs (Olthof et al. 2008; Bhatt et al. 2010; Forbes et al. 2010; Macias-Fauria et al. 2012). Our results indicated that there has been an increase in shrub cover and height in some forest tundra and tundra areas (Myers-Smith et al. 2011; Elmendorf et al. 2012b), similar to results found in experimental warming studies (Walker et al. 2006; Elmendorf et al. 2012a). In order to maintain higher rates of growth in the warming climate, shrubs need to increase access to soil nutrients. Our studies showed that warming can cause shifts in ectomycorrhizal associations with deciduous shrubs to fungal species that have greater biomass, which may increase the volume of soil available for uptake of water and nutrients (Deslippe et al. 2011). The mycorrhizal networks linked to some shrub species (e.g. Betula nana) also allows transfer of carbon between individual shrubs, which likely contributes to the shrub growth. These mechanisms combined with the increased winter soil temperature due to the deeper snow pack in shrub patches (Sturm et al. 2005) and the resulting increase in rates of decomposition and mineralization, could help explain the continued increase in shrub cover in some regions.

While most studies found increases in growth and reproduction of species (e.g. Klady et al. 2011) and in species abundance (Hudson and Henry 2009; Hill and Henry 2011; Elmendorf et al. 2012a, b), there were tundra ecosystems that showed resistance to experimental warming, both in the plant community (Hudson and Henry 2010) and the soil (Lamb et al. 2011). This resistance to warming is attributed, in part, to the initial conditions of the system, where dominant species are relatively unresponsive to the change perhaps until a higher threshold is crossed.

We found that some soil processes were responsive to climate and experimental warming while others were insensitive. Nitrogen fixation rates were strongly related to moisture conditions that promoted bryophytes or biological crust development at the regional and microtopographic scales (Stewart et al. 2011b, c). Nitrogen input from $\mathrm{N}$-fixation is important in tundra systems, as it is more than double the amount from deposition (Stewart et al. 2011a). Soil microbial diversity in tundra soils was found to be essentially the same as in soils in other biomes (Chu et al. 2010) and did not change in response to long-term warming and fertilization in a high Arctic study (Lamb et al. 2011). However, microbial diversity, especially fungal diversity, did show responses to long-term warming in a low Arctic shrub tundra (Deslippe et al. 2012). Changes in the microbial diversity and abundance will affect soil processes linked to nutrient dynamics and affect the changes in other ecosystem components, especially vegetation.

Tundra soils contain an enormous amount of carbon, much of it currently frozen in permafrost (Tarnocai et al. 2009). Warming soils tended to increase the emission of $\mathrm{CO}_{2}$ and $\mathrm{CH}_{4}$ especially in wet tundra (Hayne 2009; Edwards 2012). However, our studies were not designed to determine the source or age of the carbon emitted from the soils. Our measurements of net ecosystem production (NEP) at eight sites across the Canadian Arctic showed they were sinks for carbon during the warmest summer month, and continued measurements at most sites will help determine their source-sink state over a year and among years (Lafleur et al. 2012). At the one site that has multiple years of measurements, factors controlling gross ecosystem production (e.g. photosynthesis) are important in determining the NEP of tundra systems.

Our research during the IPY included the first modelling study of Canadian tundra (Grant et al. 2011). The modelling, based on data from a low Arctic shrub tundra site and standard climate change scenarios, indicated that internannual variability in both NPP and ER would 
increase with climate warming over the coming century, but NEP would remain positive. Under continued warming, after about 100 years ER would increase more than NPP and this type of tundra would become a carbon source. This single modelling study should be the beginning of a long-term effort to include all of the major northern terrestrial systems in Canada in the model in order to provide a comprehensive set of predictions for how they will respond to the changing climate, and to improve the model.

\section{Conclusions}

Canada's northern terrestrial ecosystems are in a state of transition as they respond to the changing climate and environment. Vegetation changes detected at regional scales were generally supported by observations and experimental studies across the northern boreal forest and into the Arctic, although variation in response in space and time was found in nearly all studies. Important soil processes, including $\mathrm{N}$-fixation and mycorrhizal associations, were found to respond to experimental conditions simulating climate change and to environmental changes in space at various scales. Microbial diversity in the soils, however, was found to be resistant to the environmental changes imposed by experiments or across landscapes, and was similar to diversity in other biomes. At present, the northern terrestrial systems in Canada we measured are sinks for atmospheric $\mathrm{CO}_{2}$, but have the potential to become important sources because of the huge stores of carbon in the soils. However, modelling of the carbon dynamics of a low Arctic tundra site indicates that the sink status of this tundra type will likely continue for the next century. Our studies during the IPY provide both a baseline for future research and monitoring and, hopefully an impetus for new research questions on the structure and function of northern terrestrial ecosystems. The combination of local knowledge and scientific studies was highly successful in our IPY projects, and is one of the strongest legacies. Our success was also in the large number of students and other researchers who were trained in northern terrestrial research and who will form the next generation of northern researchers and managers in Canada.

Acknowledgments We thank the Canadian International Polar Year Program for the opportunity to conduct and coordinate the research presented here, and all of the studies we do not cover in this summary. Additional funding was provided through the IPY Special Research Opportunity grants, Discovery Grants and Northern Supplements from the Natural Sciences and Engineering Research Council of Canada (NSERC); the Northern Scientific Training Program, Aboriginal Affairs and Northern Development Canada; ArcticNet, and from many other agencies linked to the home institutions and agencies of the co-investigators in our projects. Logistic support for some researchers was provided by the Polar Continental Shelf Program, Parks Canada, and the Arctic LTER at Toolik Lake, AK. We also acknowledge the legions of students involved in the research in the IPY projects over the life of the program, whose enthusiasm and dedication to the research helped to ensure the legacy of data, sites and collaborations among northern researchers. Finally, we thank the elders and other community members across the Canadian North who shared their knowledge with students and colleagues and enriched our projects and lives.

Open Access This article is distributed under the terms of the Creative Commons Attribution License which permits any use, distribution, and reproduction in any medium, provided the original author(s) and the source are credited.

\section{References}

ACIA (2005) Arctic climate impact assessment. Cambridge University Press, Cambridge

Agerer R (2006) Fungal relationships and their structural identity in ectomycorrhizae. Mycol Prog 5:67-107 
Andreu-Hayles L, D’Arrigo R, Anchukaitis KJ, Beck PSA, Frank D, Goetz S (2011) Varying boreal forest response to Arctic environmental change at the Firth River, Alaska. Environ Res Lett 6:045503:10, doi:10.1088/1748-9326/6/4/045503

Arft AM, Walker MD, Gurevitch J et al (1999) Response of arctic tundra plants to experimental warming: meta-analysis of the International Tundra Experiment. Ecol Monog 69:491-511

Bennington CC, Fetcher N, Vavrek MC, Shaver GR, Cummings KJ, McGraw JB (2012) Home site advantage in two long-lived arctic plant species: results from two 30-year reciprocal transplant studies. J Ecol. doi:10.1111/j.1365-2745.2012.01984.x

Bhatt US, Walker DA, Raynolds MK, Comiso JC, Epstein HE, Jia GS, Gens R, Pinzon JE, Tucker CJ, Tweedie CE, Webber PJ (2010) Circumpolar Arctic tundra vegetation change is linked to sea ice decline. Earth Interact 14:1-20

Brown CD, Johnstone JF (2012) Once burned twice shy: repeat fires reduce seed availability and alter substrate constraints on Picea mariana regeneration. For Ecol Manage 266:34-41

Brown CD, Walker X, Jameson R, Dufour Tremblay G, Hofgaard A (2010) Reproductive potential of forest expansion in the circumpolar north. Abstract, Understanding Circumpolar Ecosystems in a Changing World: Outcomes of the International Polar Year, 3-6 November 2010, Edmonton. http://www.eas.ualberta.ca/ipy/program.php. Accessed 20 August 2012

Chapin FS III, Shaver GR, Giblin AE, Nadelhoffer KJ, Laundre JA (1995) Responses of arctic tundra to experimental and observed changes in climate. Ecol 76:694-711

Chapin FS III, Sturm M, Serreze MC, McFadden JP, Key JR, Lloyd AH, McGuire AD, Rupp TS, Lynch AH, Schimel JP, Beringer J, Chapman WL, Epstein HE, Euskirchen ES, Hinzman LD, Jia G, Ping CL, Tape KD, Thompson CDC, Walker DA, Welker JM (2005) Role of land-surface changes in arctic summer warming. Science 310:657-660

Chen W, Russell DE, Gunn A, Croft B, Chen WR, Fernandes R, Zhao H, Li J, Zhang Y, Koehler K, Olthof I, Fraser RH, Leblanc SG, Henry GHR, White RG, and Finstad GL (2012a) Changes over the past 50 years in habitat conditions during winter and pre-calving migration for the Bathurst Caribou herd in northern Canada. Biodiversity (in review)

Chen W, Russell DE, Gunn A, Croft B, Chen WR, Fernandes R, Zhao H, Li J, Zhang Y, Koehler K, Olthof I, Fraser RH, Leblanc SG, Henry GHR, White RG, Finstad GL (2012b) Changes in habitat indicators for the calving ground and summer range of Bathurst caribou herd in Northern Canada. Arctic (in review)

Chu H, Fierer N, Lauber CL, Caporaso JG, Knight R, Grogan P (2010) Soil bacterial diversity in the Arctic is not fundamentally different from that found in other biomes. Environ Microbiol 12:2998-3006

Cuerrier A, Downing A, Johnstone JF, Hermanutz L, Siegwart Collier L, Elders and Youth Participants of Nain and Old Crow (2012) Our plants, our land: bridging Aboriginal generations through cross-cultural plant workshops. Polar Geogr. doi:10.1080/1088937X.2012.684156

Dagg J, Lafleur P (2011) Vegetation community, foliar nitrogen, and temperature effects on tundra $\mathrm{CO}_{2}$ exchange across a soil moisture gradient. Arct Antarct Alp Res 43:189-197

Danby RK, Hik DS (2007) Evidence of recent treeline dynamics in southwest Yukon from aerial photographs. Arctic 60:411-420

Danby RK, Williamson SN, Hik DS (2010) Trends in snow cover and NDVI for southwest Yukon, Canada, derived from MODIS, 2000-2008. Abstract, International Polar Year Oslo Science Conference, 8-12 June 2010, Oslo, http://ipy-osc.no/abstract/383054

D’Arrigo R, Wilson R, Liepert B, Cherubini P (2008) On the 'divergence problem' in northern forests: a review of the tree-ring evidence and possible causes. Global Planet Change 60:289-305

Deslippe JR, Egger KN, Henry GHR (2005) Impacts of warming and fertilization on nitrogen-fixing microbial communities in the Canadian High Arctic. FEMS Microbiol Ecol 53:41-50

Deslippe JR, Simard SW (2011) Below-ground carbon transfer among Betula nana may increase with warming in Arctic tundra. New Phytol 192:689-698

Deslippe JR, Hartmann M, Mohn WW, Simard SW (2011) Long-term experimental manipulation of climate alters the ectomycorrhizal community of Betula nana in Arctic tundra. Global Change Biol 17:1625-1636

Deslippe JR, Hartmann M, Simard SW, Mohn WW (2012) Long-term warming alters the composition of Arctic soil microbial communities. FEMS Microbiol Ecol. doi:10.1111/j.1574-6941.2012.01350.x

Downing A, Cuerrier A (2011) A synthesis of the impacts of climate change on the First Nations and Inuit of Canada. Indian J Trad Know 10:57-70

Dufour Tremblay G, Boudreau S, Tremblay B, Levesque E (2010) Altitudinal treeline dynamics in response to climate change in the vicinity of Kangiqsualujjuaq (Nunavik, Québec). Abstract, Understanding Circumpolar Ecosystems in a Changing World: Outcomes of the International Polar Year, 3-6 November 2010, Edmonton. http://www.eas.ualberta.ca/ipy/program.php. Accessed 20 August 2012 
Dufour Tremblay G, Boudreau S (2011) Black spruce regeneration at the treeline ecotone: synergistic impacts of climate change and caribou activity. Can J For Res 41:460-468

Edwards M (2012) Ecosystem response to environmental change: How does experimental warming affect the structure and function of three Arctic plant communities? Dissertation, University of British Columbia

Elmendorf SC, Henry GHR, Hollister RD, Björk RG, Bjorkman AD, Callaghan TV, Siegwart-Collier L, Cooper EJ, Cornelissen JHC, Day TA, Maria Fosaa A, Gould WA, Grétarsdóttir J, Harte J, Hermanutz L, Hik DS, Hofgaard A, Jarrad F, Jónsdóttir IS, Keuper F, Klanderud K, Klein JA, Koh S, Kudo G, Lang S, Loewen V, May JL, Mercado J, Michelsen A, Molau U, Myers-Smith IH, Oberbauer SF, Pieper S, Post E, Rixen C, Robinson CH, Schmidt NM, Shaver GR, Stenström A, Tolvanen A, Totland Ø, Troxler T, Wahren C-H, Webber PJ, Welker JM, Wookey PA (2012a) Global assessment of experimental climate warming on tundra vegetation: heterogeneity over space and time. Ecol Lett 15:164-175

Elmendorf SC, Henry GHR, Hollister RD, Bjork RG, Boulanger-Lapointe N, Cooper EJ, Cornelissen JHC, Day TD, Dorrepaal D, Elumeeva TG, Gill M, Gould WA, Grétarsdóttir J, Harte JC, Hik DS, Hofgaard A, Jarrad F, Johnson DR, Johnstone JF, Jónsdóttir IS, Jorgenson J, Klanderud K, Klein JA, Koh S, Kudo G, Lara M, Lévesque E, Magnússon B, May JL, Mercado J, Michelsen A, Molau U, Myers-Smith I, Oberbauer SF, Onipchenko VG, Rixen C, Schmidt NM, Shaver GR, Spasojevic MJ, Pórhallsdóttir PE, Tolvanen A, Tweedie CE, Wahren C-H, Walker X, Webber PJ, Wipf S (2012b) Plot scale evidence of tundra vegetation change and links to recent climate warming. Nat Clim Change 2:453-457. doi:10.1038/NCLIMATE1465

Epstein HE, Beringer J, Gould WA, Lloyd AH, Thompson CD, Chapin FS III, Michaelson GJ, Ping CL, Rupp TS, Walker DA (2004) The nature of spatial transitions in the Arctic. J Biogeogr 31:1917-1933

Forbes BC, Fauria MM, Zetterberg P (2010) Russian Arctic warming and 'greening' are closely tracked by tundra shrub willows. Global Change Biol 16:1542-1554

Fraser RH, Olthof I, Carrière M, Deschamps A, Pouliot D (2012) Detecting long-term changes to vegetation in northern Canada using the Landsat satellite image archive. Environ Res Lett 6:045502. doi:10.1088/ $1748-9326 / 6 / 4 / 045502$

Gamache I, Payette S (2005) Latitudinal response of subarctic tree lines to recent climate change in eastern Canada. J Biogeogr 32:849-862

Gould WA, Raynolds M, Walker DA (2003) Vegetation, plant biomass, and net primary productivity patterns in the Canadian Arctic. J Geophys Res 108(D2):8167. doi:10.1029/2001JD000948

Grant RF (2001) A review of the Canadian ecosystem model ecosys. In: Shaffer M (ed) Modeling of carbon and nitrogen dynamics for soil management. CRC Press, Boca Raton, pp 173-263

Grant RF, Humphreys ER, Lafleur PM, Dimitrov DD (2011) Ecological controls on net ecosystem productivity of a mesic arctic tundra under current and future climates. J Geophys Res Biogeosci 116:G01031. doi:10.1029/2010JG001555

Griffis TJ, Rouse WR, Waddington JM (2000) Interannual variability of net ecosystem CO2 exchange at a subarctic fen. Global Biogeochem Cycles 14:1109-1121

Harper KA, Albertsen E (2010) At the front of forest expansion into tundra: the structure of tree islands within the forestt undra ecotone. Abstract, Understanding Circumpolar Ecosystems in a Changing World: Outcomes of the International Polar Year, 3-6 November 2010, Edmonton. http://www.eas.ualberta.ca/ipy/program.php. Accessed 20 August 2012

Hayne SL (2009) Controls on atmospheric exchanges of carbon dioxide and methane for a variety of Arctic tundra types. Dissertation, Carleton University

Heikkinen JEP, Virtanen T, Huttunen JT, Elsakov V, Martikainen PJ (2004) Carbon balance of eastern European tundra. Global Biogeochem Cycles 18:GB1023. doi:10.1029/2003GB002054

Henry GHR, Molau U (1997) Tundra plants and climate change: the International Tundra Experiment (ITEX). Global Change Biol 3(Suppl 1):1-9

Henry GHR, Levesque E, Hermanutz L, Cuerrier A, Jacobs JD (2012) Impacts of vegetation change in the Canadian Arctic: local and regional assessments. Annual Report, ArcitcNet, Université Laval, Quebec

Hill GB, Henry GHR (2011) Responses of High Arctic wet sedge tundra to climate warming since 1980. Global Change Biol 17:276-287. doi:10.1111/j.1365-2486.2010.02244.x

Hofgaard A, Harper KA (2011) Tree recruitment, growth and distribution at the circumpolar forest- tundra transition: Introduction. Can J For Res 41:435-436

Hofgaard A, Rees G (eds) (2008) PPS Arctic Manual. Common protocols for field measurements and handling of collected materials. Unpublished, http://ppsarctic.nina.no/files/PPSArctic

Hudson JMG, Henry GHR (2009) Increased plant biomass in a High Arctic heath community from 1981 to 2008. Ecol 90:2657-2663

Hudson JMG, Henry GHR (2010) High Arctic plant community resists 15 years of experimental warming. J Ecol 98:1035-1041 
Hudson JMG, Henry GHR, Cornwell WK (2011) Taller and larger: shifts in Arctic tundra leaf traits after 16 years of experimental warming. Global Change Biol 17:1013-1021

Humphreys ER, Lafleur PM (2011) Does earlier snowmelt lead to greater $\mathrm{CO}_{2}$ sequestration in two low Arctic tundra ecosystems? Geophys Res Lett 38. doi:10.1029/2011GL 047339

Intergovernmental Panel on Climate Change (2007) IPCC fourth assessment report (AR4). Working Group 1, The Physical Science Basis. http:/www.ipcc.ch/publications_and_data/ar4/wg1/en/contents.html

Johnstone JF, Chapin FS III (2003) Non-equilibrium succession dynamics indicate continued northern migration of lodgepole pine. Global Change Biol 10:1401-1409

Jolly D, Berkes F, Castleden J, Nichols T, Community of Sachs Harbour (2002) We can't predict the weather like we used to. In: Krupnik I, Jolly D (eds) The earth is faster now: indigenous observations of Arctic environmental change. Arctic Research Consortium of the United States, Fairbanks, pp 92-125

Klady RA, Henry GHR, Lemay V (2011) Changes in high arctic tundra plant reproduction in response to long-term experimental warming. Global Change Biol 17:1611-1624

Kohn LM, Stasovski E (1990) The mycorrhizal status of plants at Alexandra Fiord, Ellesmere Island, Canada, a high Arctic site. Mycologia 82:23-35

Lafleur PM, Humphreys ER, St Louis VL, Myklebust MC, Papakyriakou T, Poissant L, Barker JD, Pilote M, Swystun KA (2012) Variation in peak growing season net ecosystem production across the Canadian Arctic. Environ Sci Tech 46:7971-7977

Lafleur PM, Griffis TJ, Rouse WR (2001) Interannual variability in net ecosystem CO2 exchange at the Arctic treeline. Arct Antarct Alp Res 33:149-157

Lamb EG, Han S, Lanoil BD, Henry GHR, Brummell ME, Banerjee S, Siciliano SD (2011) A High Arctic soil ecosystem resists long-term environmental manipulations. Glob Change Biol 17:3187-3194. doi:10.1111/j.1365-2486.2011.02431.x

Lantz TC, Kokelj SV, Gergel SE, Henry GHR (2009) Relative impacts of disturbance and temperature: persistent changes in microenvironment and vegetation in retrogressive thaw slumps. Global Change Biol $15: 1664-1675$

Lantz TC, Gergel SE, Henry GHR (2010) Response of green alder (Alnus viridis subsp. fruticosa) patch dynamics and plant community composition to fire and regional temperature in north-western Canada. J Biogeogr 37:1597-1610

MacDonald GM, Edwards TWD, Moser KA, Pienitz R, Smol JP (1993) Rapid response of treeline vegetation and lakes to past climate warming. Nature 361:243-246

Macias-Fauria M, Forbes BC, Zetterberg P, Kumpula T (2012) Eurasian Arctic greening reveals teleconnections and the potential for structurally novel ecosystems. Nat Clim Change. doi:10.1038/NCLIMATE1558

Mamet SD, Kershaw GP (2011) Subarctic and alpine tree line dynamics during the last 400 years in northwestern and central Canada. J Biogeogr. doi:10.1111/j.1365-2699.2011.02642.x

McGhee RW (2001) Ancient people of the Arctic. UBC Press, Vancouver

McGuire AD, Ruess RW, Lloyd A, Yarie J, Clein JS, Juday GP (2010) Vulnerability of white spruce tree growth in interior Alaska in response to climate variability: dendrochronological, demographic, and experimental perspectives. Can J For Res 40:1197-1209

McLeod KL (2001) The ecology of Picea glauca (Moench) Voss at its range limits in Northwest Canada. Dissertation, University of British Columbia

Miyamoto Y, Griesbauer HP, Green DS (2010) Growth responses of three coexisting conifer species to climate across wide geographic and climate ranges in Yukon and British Columbia. For Ecol Manag 259:514-523

Muc M, Freedman B, Svoboda J (1989) Vascular plant communities of a polar oasis at Alexandra Fiord $\left(79^{\circ} \mathrm{N}\right)$, Ellesmere Island, Canada. Can J Bot 67:1126-1136

Munier A, Hermanutz L, Jacobs JD, Lewis K (2010) The interacting effects of ground disturbance and herbivory on seedling establishment: implications for treeline advance with climate warming. Plant Ecol 210:19-30

Myers-Smith IH (2011) Shrub encroachment in arctic and alpine tundra: mechanisms of expansion and ecosystem impacts. Dissertation, University of Alberta

Myers-Smith IH, Hik DS, Kennedy C, Cooley D, Johnstone JF, Kenney A, Krebs CJ (2011) Expansion of canopy-forming willows over the twentieth century on Herschel Island, Yukon Territory, Canada. Ambio 40:610-623

Myers-Smith IH, Forbes BC, Wilmking M, Hallinger M, Lantz T, Blok D, Tape KD, Macias-Fauria M, SassKlaassen U, Lévesque E, Boudreau S, Ropars S, Hermanutz L, Trant A, Siegwart Collier L, Weijers S, Rozema J, Rayback SA, Schmidt NM, Schaepman-Strub G, Wipf S, Rixen C, Ménard CB, Venn S, Goetz S, Andreu-Hayles L, Elmendorf S, Ravolainen V, Welker J, Grogan P, Epstein HE, Hik DS (2012) Shrub expansion in tundra ecosystems: dynamics, impacts and research priorities. Environ Res Lett 6:045509. doi:10.1088/1748-9326/6/4/045509 
Nishimura PH, Laroque CP (2011) Observed continentality in radial growth-climate relationships in a twelve site network in western Labrador, Canada. Dendrochron 29:17-23

Oberbauer SF, Tweedie CE, Welker JM, Fahnestock JT, Henry GHR, Webber PJ, Hollister RD, Walker MD, Kuchy A, Elmore E, Starr G (2007) Tundra $\mathrm{CO}_{2}$ fluxes in response to experimental warming across latitudinal and moisture gradients. Ecol Monog 77:221-238

Oechel WC, Vourlitis GL, Verfaillie J Jr, Crawford T, Brooks S, Dumas E, Hope A, Stow D, Boynton B, Nosov V, Zulueta R (2000) A scaling approach for quantifying the net $\mathrm{CO}_{2}$ flux of the Kuparuk River Basin, Alaska. Global Change Biol 6:160-173

Olivas PC, Oberbauer SF, Tweedie CE, Oechel WC, Kuchy A (2010) Response of $\mathrm{CO}_{2}$ flux components of Alaskan Coastal Plain tundra to shifts in water table. J Geophys Res 115. doi:10.1029/2009JR001254

Olthof I, Pouliot D, Latifovic R, Chen W (2008) Recent (1986-2006) vegetation-specific NDVI trends in northern Canada from satellite data. Arctic 61:381-394

Park RW (2010) Frozen coasts and the development of Inuit culture in the North American Arctic. In: Martini IP, Chesworth W (eds) Landscapes and societies. Springer Science+Business Media B.V, New York

Payette S (1983) The forest tundra and present tree lines of the northern Québec-Labrador Peninsula. Nordicana 47:3-23

Payette S, Gagnon R (1979) Tree-line dynamics in Ungava peninsula, northern Quebec. Holarct Ecol 2:239-248

Payette S, Fortin MJ, Gamache I (2001) The subarctic forest-tundra: the structure of a biome in a changing climate. BioSci 51:709-718

Porter TJ, Pisaric MFJ (2011) Temperature-growth divergence in white spruce forests of Old Crow Flats, Yukon Territory, and adjacent regions of northwestern North America. Global Change Biol 17:3418-3430

Ritchie JC (1987) Postglacial vegetation of Canada. Cambridge University Press, Cambridge

Reithmeier L (2011) Facilitation of ectomycorrhizal colonization of Picea mariana by alternate host plants above treeline. Dissertation, Dalhousie University

Rolph S (2003) Effects of a ten-year climate warming experiment on nitrogen cycling in high Arctic tundra. Dissertation, University of British Columbia

Ropars P, Boudreau S (2012) Shrub expansion at the forest-tundra ecotone: spatial heterogeneity linked to local topography. Environ Res Lett 7:015501. doi:10.1088/1748-9326/7/1/015501

Shaver GR, Canadell J, Chapin FS III, Gurevitch J, Harte J, Henry G, Ineson P, Jonasson S, Melillo J, Pitelka L, Rustad L (2000) Global warming and terrestrial ecosystems: a conceptual framework for analysis. BioSci 50:871-882

Savidge R (2010) Ancient Yukon trees of southeastern Beringia. Abstract, Understanding Circumpolar Ecosystems in a Changing World: Outcomes of the International Polar Year, 3-6 November 2010, Edmonton. http://www.eas.ualberta.ca/ipy/program.php. Accessed 20 August 2012

Schuur EAG, Bockheim J, Canadell JG, Euskirchen E, Field CB, Goryachkin SV, Hagemann S, Kuhry P, Lafleur PM, Lee H, Mazhitova G, Nelson FE, Rinke A, Romanovsky VE, Shiklomanov N, Tarnocai C, Venevsky S, Vogel JG, Zimov SA (2008) Vulnerability of permafrost carbon to climate change: implications for the global carbon cycle. BioSci 58:701-714. doi:10.1641/B580807

Schimel JP, Bilborough C, Welker JM (2004) Increased snow depth affects microbial activity and nitrogen mineralization in two Arctic tundra communities. Soil Biol Biochem 36:217-227

Stewart KJ, Coxson D, Grogan P (2011a) Nitrogen inputs by associative cyanobacteria across a low Arctic tundra landscape. Arct Antarct Alp Res 43:267-278

Stewart KJ, Coxson DS, Siciliano SD (2011b) Small-scale spatial patterns in N2-fixation and nutrient availability in an arctic hummock-hollow ecosystem. Soil Biol Biochem 43:133-140

Stewart KJ, Lamb EG, Coxson DS, Siciliano SD (2011c) Bryophyte-cyanobacterial associations as a key factor in N2-fixation across the Canadian Arctic. Plant Soil. doi:10.1007/s11104-011-0750-X

Sturm M, Schimel J, Michaelson J, Welker JM, Oberbauer SF, Liston GE, Fahnestock J, Romanovsky VE (2005) Winter biological processes could help convert tundra to shrubland. BioSci 55:17-26

Svoboda J, Freedman B (eds) (1994) Ecology of a polar oasis Alexandra Fiord, Ellesmere Island, Canada. Captus University Publications, Toronto

Svoboda J, Henry GHR (1987) Succession in marginal arctic environments. Arct Alp Res 19:373-384

Tape KEN, Sturm M, Racine C (2006) The evidence for shrub expansion in Northern Alaska and the PanArctic. Global Change Biol 12:686-702

Tarnocai C (1999) The effect of climate warming on the carbon balance of Cryosols in Canada. Permafrost Periglacial Process 10:251-263

Tarnocai C, Canadell JG, Schuur EAG, Kuhry P, Mazhitova G, Zimov, S (2009) Soil organic carbon pools in the northern circumpolar permafrost region. Global Biogeochem Cycles 23:GB2023. doi:10.1029/ 2008GB003327

Timoney KP, La Roi GH, Zoltai SC, Robinson AL (1992) The high subarctic forest-tundra of northwestern Canada: position, width, and vegetation gradients in relation to climate. Arctic 45:1-9 
Trant AJ, Jacobs JD, Sable T (2012) Teaching and learning about climate change with Innu Environmental Guardians. Polar Geogr. doi:10.1080/1088937X.2012.682229

Tremblay B, Lévesque E, Boudreau B (2012) Recent expansion of erect shrubs in the Low Arctic: evidence from eastern Nunavik. Environ Res Lett 7: 035501 (11p)

Trindale M, Bell T, Laroque CP, Jacobs JD, Hermanuz L (2011) Dendroclimatic response of a coastal alpine treeline ecotone: a multispecies perspective from Labrador. Can J For Res 41:469-478

Walker DA (2000) Hierarchical subdivision of arctic tundra based on vegetation response to climate, parent material, and topography. Global Change Biol 6:19-34

Walker XA (2011) The reproduction, establishment, and growth of white spruce in the forest tundra ecotone of the Inuvik-Tuktoyaktuk region. Dissertation, University of British Columbia

Walker DA, Raynolds MK, Daniëls FJA, Einarsson E, Elvebakk A, Gould WA, Katenin AE, Kholod SS, Markon CJ, Melnikov ES, Moskalenko NG, Talbot SS, Yurtsev BA et al (2005) The Circumpolar Arctic vegetation map. J Veg Sci 16:267-282

Walker JK, Egger KN, Henry GHR (2008) Long-term experimental warming alters nitrogen-cycling communities but site factors remain the primary drivers of community structure in high arctic tundra soils. ISME J 2:982-985

Walker MD, Wahren C-H, Hollister RD, Henry GHR, Ahlquist L, Alatalo J, Bret-Harte MS, Calef M, Callaghan TV, Carroll A, Epstein HE, Jónsdóttir IS, Klein JA, Magnússon B, Molau U, Oberbauer SF, Rewa S, Robinson CH, Shaver GR, Suding KN, Thompson C, Tolvanen A, Totland Ø, Turner L, Tweedie CE, Webber PJ, Wookey PA (2006) Plant community responses to experimental warming across the tundra biome. Proc Natl Acad Sci USA 103:1342-1346

Walker XA, Henry GHR, McLeod KL, Hofgaard A (2012) Reproduction and seedling establishment of Picea glauca across the northernmost forest-tundra region in Canada. Global Change Biol. doi:10.1111/j.13652486.2012.02769.x

Wang M, Overland JE (2004) Detecting Arctic climate change using Köppen climate classification. Clim Chang 67:43-62

Welker JM, Fahnestock JT, Henry GHR, O’Dea KA, Chimner RA (2004) $\mathrm{CO}_{2}$ exchange in three Canadian High Arctic ecosystems: response to long-term experimental warming. Global Change Biol 10:19811995

Wolfe BB, Humphries MM, Pisaric MFJ, Balasubramaniam AM, Burn CR, Chan L, Cooley D, Froese DG, Graupe S, Hall RI, Lantz T, Porter TJ, Roy-Leveillee P, Turner KW, Wesche SD, Williams M (2011) Environmental Change and Traditional Use of the Old Crow Flats in Northern Canada: An IPY Opportunity to Meet the Challenges of the New Northern Research Paradigm. Arctic 64:127-135

Zalatan R, Gunn A, Henry GHR (2006) Long-term abundance patterns of barren-ground caribou using trampling scars on roots of Picea mariana in the Northwest Territories, Canada. Arct Antarct Alp Res 38:624-630 